OPEN ACCESS

Edited by:

Christina Cowger,

Plant Science Research Unit

(USDA-ARS), United States

Reviewed by:

Lucy N. Moleleki,

University of Pretoria, South Africa Sutton Mooney,

Washington State University, United States

*Correspondence: Suha H. Jabaji suha.jabaji@mcgill.ca

Specialty section: This article was submitted to Plant Microbe Interactions, a section of the journal

Frontiers in Plant Science

Received: 01 November 2019 Accepted: 28 May 2020

Published: 24 June 2020

Citation:

Samsatly J, Bayen S and Jabaji SH (2020) Vitamin B6 Is Under

a Tight Balance During Disease Development by Rhizoctonia solani on Different Cultivars of Potato and on Arabidopsis thaliana Mutants.

Front. Plant Sci. 11:875 doi: $10.3389 /$ fpls.2020.00875

\section{Vitamin B6 Is Under a Tight Balance During Disease Development by Rhizoctonia solani on Different Cultivars of Potato and on Arabidopsis thaliana Mutants}

\author{
Jamil Samsatly', Stéphane Bayen ${ }^{2}$ and Suha H. Jabaji ${ }^{*}$ \\ ${ }^{1}$ Department of Plant Science, McGill University, Sainte-Anne-de-Bellevue, QC, Canada, ${ }^{2}$ Department of Food Science \\ and Agricultural Chemistry, McGill University, Sainte-Anne-de-Bellevue, QC, Canada
}

Vitamin B6 is well recognized as an essential antioxidant and plays a role in stress responses. Co-expression of plant and pathogen-derived vitamin B6 genes is critical during disease development of $R$. solani. However, little is known about the functionality of vitamin B6 vitamers during plant- $R$. solani interactions and their involvement in disease tolerance. Here, we explored the possible involvement of vitamin B6 during disease progression of potato cultivars of different susceptibility levels to $R$. solani. A distinct pattern of gene expression, pyridoxine (PN) concentration, and fungal biomass was found in the susceptible cv. Russet Burbank and tolerant cv. Chieftain. Accumulation of reactive oxygen species (ROS) in $R$. solani mycelia or plant tissues applying non-fluorescence or fluorescence methods was related to up-regulation in the vitamin B6 pathway and is indicative of oxidative stress. Russet Burbank was susceptible to $R$. solani, which was linked to reduced amounts of VB6 content. Prior to infection, constitutive PN levels were significantly higher in Russet Burbank by 1.6-fold compared to Chieftain. Upon infection with $R$. solani, PN levels in infected tissues increased more in Chieftain (1.7-fold) compared to Russet Burbank (1.4fold). $R$. solani AG3 infection of potato sprouts in both cultivars significantly activates the fungal and plant vitamin B6 and glutathione-S-transferase (GST) genes in a tissuespecific response. Significant fold increases of transcript abundance of the fungal genes ranged from a minimum of 3.60 (RsolSG3GST) to a maximum of 13.91 (RsolAG3PDX2) in the surrounding necrotic lesion tissues (zone 1). On the other hand, PCA showed that the top plant genes STGST and STPDX1.1 were linked to both tissues of necrotic lesions (zone 2) and their surrounding areas of necrotic lesions. Functional characterization of Arabidopsis $p d x 1.3$ mutants challenged with $R$. solani provided evidence into the role of the vitamin B6 pathway in the maintenance of plant tolerance during disease progression. Overall, we demonstrate that the production of vitamin VB6 is under tight control and is an essential determinant of disease development during the interaction of $R$. solani with potato cultivars.

Keywords: vitamin B6, de novo pathway, salvage pathway, Rhizoctonia solani, oxidative stress, biotic stress, PDX genes, antioxidant genes 


\section{INTRODUCTION}

Rhizoctonia disease of potato or blackscurf, caused by Rhizoctonia solani Kuhn (teliomorph Thanatephorus cucumeris Frank Donk), occurs in most potato producing areas worldwide. Isolates of $R$. solani anastomosis group AG3 are recognized as the etiological agents for this disease. Disease symptoms manifest on potato sprouts, stolons, and roots, causing sprout nipping and cankers, which are reddish to brown lesions on stolons and roots (Gutierrez et al., 1997). Severe damage at this stage leads to uneven crop stand, and reduced yield (Hide and Horrocks, 1994; Hide et al., 1996). Tubers are also affected with the appearance of black sclerotia (resting vegetative bodies of the fungus). To date, no variety has immunity to the sprout nipping and stem lesion phase, and breeding for resistance does not control the pathogen. However, some varieties show varying degrees of resistance to the formation of sclerotia on tubers.

Like many other necrotrophic pathogens, $R$. solani causes extensive necrosis and tissue maceration (Laluk and Mengiste, 2010). The shared elements in early disease development of $R$. solani isolates are the intimate association of fungal hyphae with the epidermis of the host forming infection cushion or aggregates, tissue penetration, and maceration by cell wall degrading enzymes and other enzymes which eventually leads to tissue browning associated with high levels of reactive oxygen species (ROS) and tissue death (Keijer, 1996; Sneh et al., 2013). ROS molecules are highly reactive and toxic to biological molecules, and are not only essential regulators of plant growth, but are involved in limiting pathogen spread, induction of cell death and signal transduction in host-plant interactions (Torres, 2010; Barna et al., 2012). There is also increasing evidence that fungi also produce ROS during pathogenic interactions (Daub and Ehrenshaft, 2000; Samsatly et al., 2018). Therefore, the regulation of ROS in fungal cells and tolerance to external ROS produced by the host plant represent a balanced control and detoxification by both partners which can govern the fate of disease progression of necrotrophic pathogens (Heller and Tudzynski, 2011). To fine-tune and maintain this balance, plant and fungal cells possess a complex battery of protective mechanisms such as oxalic acid or the NADPH oxidase RBohD (Torres et al., 2005; Kadota et al., 2015), or ROS-quenching molecules including vitamin B6 (VB6) and several antioxidation enzymes including superoxide dismutase (SOD), catalase (CAT), ascorbate peroxidase (APX), glutathione -S-transferase (GST), and glutathione reductase (Das and Roychoudhury, 2014; Samsatly et al., 2015; Zhang et al., 2015; Girard et al., 2017). In the case of $R$. solani, the initiation of basal resistance in plants to R. solani in different pathosystems is closely linked to ROSscavenging mechanisms, oxylipins production, cell wall-bound phenolic compounds, and the build-up of metabolites related to vitamin B6 biosynthetic pathway (Taheri and Tarighi, 2011; Nikraftar et al., 2013; Aliferis et al., 2014; Foley et al., 2016; Samsatly et al., 2018).

Vitamin B6 plays a critical role in all living organisms and is recognized as an important cofactor required for many enzymatic reactions (Hellmann and Mooney, 2010). Vitamin B6 is a collection of six vitamers: pyridoxine (PN), pyridoxal
(PL), pyridoxamine (PM), and their phosphorylated derivatives (Fitzpatrick et al., 2012; Vanderschuren et al., 2013). In plants and fungi, the de novo biosynthesis of VB6 vitamers (the socalled DXP-independent pathway) requires two pyridoxal protein families (PDX1 and PDX2) that are highly conserved. PDX1 and PDX2 proteins contain the glutamine amidotransferase where PDX1 functions as the synthase and PDX2 constitutes the glutaminase domain (Raschle et al., 2005; Fitzpatrick et al., 2007). Another important component of the VB6 biosynthetic machinery is the salvage pathway, which is responsible for the interconversion between the different forms of VB6 vitamers (González-Guerrero et al., 2007; Herrero et al., 2011; Rueschhoff et al., 2012). It includes pyridoxal reductase (PLR), a downstream enzyme in the VB6 biosynthesis pathway, which converts PL into PN (Morita et al., 2004; Herrero et al., 2011).

In the last decade, the regulatory function of key genes involved in the VB6 biosynthetic pathways was characterized in the model plant Arabidopsis, recognizing the importance of VB6 in plant development and response to stress (Hellmann and Mooney, 2010). There are three PDX1 homologs in Arabidopsis, two (PDX1.1 and PDX1.3) of which are catalytically active, and they encode PDX (Titiz et al., 2006; Tambasco-Studart et al., 2007). PDX1.3 is required for disease resistance to bacterial and fungal diseases in Arabidopsis (Moccand et al., 2014; Zhang et al., 2014, 2015). In contrast to Arabidopsis, potato (Solanum tuberosum L.) has only two PDX1 homologs (PDX1.1 and PDX1.2), and only PDX1.1 is catalytically active (Mooney et al., 2013). Several studies had shown that VB6 is a potent antioxidant with quenching ROS ability that matches that of tocopherols or ascorbic acid. This novel role of VB6 as ROS scavenger and its ability to increase resistance against biotic and abiotic types of stress has been demonstrated in microbe-microbe (Chamoun and Jabaji, 2011; Gkarmiri et al., 2015) and in plant-microbe interactions (Ehrenshaft et al., 1999; Benabdellah et al., 2009; Mooney et al., 2009; Vanderschuren et al., 2013). During plant-microbe interactions, the plant-derived VB6 genes, involved in the de novo biosynthetic pathway, were upregulated in response to various stresses (Denslow et al., 2005; Bagri et al., 2018; Chandrasekaran and Chun, 2018; Samsatly et al., 2018). These results imply that VB6 vitamers might contribute to disease resistance in modulating plant defense responses against different types of pathogens. Zhang et al. (2014) provided direct evidence supporting this notion by examining Arabidopsis mutant ecotypes that are defective in the de novo, and the salvage pathways of VB6 biosynthesis. Mutations in the Arabidopsis PDX1.2 and PDX1.3 genes involved in the de novo pathway increased disease levels caused by Botrytis cinerea and decreased the content level of VB6 (Zhang et al., 2014, 2015). Despite these studies on the regulation and co-expression of VB6 genes in the host and the pathogen of the de novo and salvage biosynthetic pathways during host-pathogen interactions remain limited to the best of our knowledge to only one study (Samsatly et al., 2018).

In a preceding research, we provided evidence that genes of vitamin B6 biosynthetic machinery are implicated as antioxidants in response to oxidative stress formed during potato- $R$. solani interaction and that VB6 genes are co-expressed 
in both the potato and $R$. solani during their interaction. We also provided evidence that the differential transcription of genes in infected necrotic tissues and their surrounding areas is spatially regulated (Samsatly et al., 2018). These results indicate that VB6 antioxidant genes are critical during disease development from the host's viewpoint, and are crucial for detoxification and pathogenicity from the pathogen's perspective. Therefore, developing new strategies to combat yield losses in potato requires a thorough understanding of the antioxidant genes and gene regulatory networks underlying the plant defense response, especially in existing tolerant breeding potato cultivars.

In this study, we expanded the research to first, test whether potato genotypes containing variable amounts of VB6 (Mooney et al., 2013) would exhibit distinct degrees of tolerance to $R$. solani AG3, and that this tolerance is tightly linked with the differential expression of genes of VB6 de novo and salvage biosynthetic pathways. Second, we used a LC-MS-based method to report on the content of the VB6 vitamer, pyridoxine (PN) in infected potato cultivars and to assess $R$. solani-induced expression of VB6 biosynthetic genes. Third, we examined phenotypes of Arabidopsis mutants with defects in the de novo pathway of VB6 biosynthesis against infection by $R$. solani, compared their VB6 content, and providing evidence that mutations in PDX1.3 led to increased disease, suggesting the role of VB6 in plant resistance.

\section{MATERIALS AND METHODS}

\section{Biological Material and Inoculation Rhizoctonia solani Inoculum Preparation}

Cultures of $R$. solani AG3 isolate Rs114 (ATCC 10183), a pathogen of potato, and $R$. solani AG4 (subgroup HG-I) isolate A76, a pathogen of Arabidopsis was provided by M. Cubeta, North Carolina University, United States. Strains were retrieved from $10 \%$ glycerol stock stored at $-80^{\circ} \mathrm{C}$ on potato dextrose agar (PDA; Difco Laboratories) and grown for 3 days at $24^{\circ} \mathrm{C}$ in the dark and used as a source of inoculum for plant infection. Strips of PDA $(2 \mathrm{~cm} \times 8 \mathrm{~cm})$ containing mycelia growth $R$. solani served as the inoculum. For RNA and DNA extraction, cultures of $R$. solani strains of AG3 and AG4 were grown on PDA overlaid with cellophane membrane following the method of Samsatly et al. (2018).

\section{Solanum tuberosum L. Growth Conditions}

Certified potato tubers with different susceptibility levels to $R$. solani were used in this study. Solanum tuberosum cv. Russet Burbank, susceptible to $R$. solani (Thangavel et al., 2014) was provided by D.J. Donnelly (McGill University), and S. tuberosum cv. Chieftain, a tolerant to $R$. solani (Dowley, 1972) was obtained from the Northern Horticultural Research/SPUD Unit, New Liskeard Agricultural Research Station, University of Guelph (Canada). For sprout induction, uniform-sized tubers, previously kept at $4^{\circ} \mathrm{C}$ in the dark, were sprouted for 12 days under controlled conditions following the method of Samsatly et al. (2018). Sprout tips of $3 \mathrm{~cm}$ in length were sprayed with $1.5 \mathrm{~mL}$ solution of $\mathrm{CaNO}_{3}(0.5 \mathrm{M})$ to prevent browning. Inoculation of sprouts with $R$. solani was performed when sprouts were $8 \mathrm{~cm}$ in length.

\section{Sprout Inoculation and Tissue Collection}

To induce $R$. solani infections on potato sprouts, excised sprouts $(8 \mathrm{~cm}$ in length) were sandwiched with two PDA strips $(2 \mathrm{~cm} \times 8 \mathrm{~cm})$ of a 3 -day-old $R$. solani AG3 Rs114 culture and placed in sterile Pyrex trays $(40 \mathrm{~cm} \times 26 \mathrm{~cm})$ lined with wet sterile Whatman No. 1 paper as fully described in Samsatly et al. (2018). Mock-inoculated control potato sprouts were sandwiched with sterile PDA strips. There were 3 biological replicates per treatment and each treatment replicate consisted of 4 excised potato sprouts.

Pyrex trays were covered with transparent plastic film, and placed in a growth chamber under photosynthetically inactive black light $(365 \mathrm{~nm})$ at $24^{\circ} \mathrm{C}$. PDA strips were removed $120 \mathrm{~h}$ post-inoculation (HPI) of potato sprouts to reveal the infection areas with visible necrotic lesions on the sprouts. This time point was optimal to secure the beginning of infection cushions and mycelial aggregates that were stereoscopically examined (Figure 1). Two distinct zones were sampled from potato stolons. Zone 1 consisted of a one-cm area bordering the lesions and zone 2 contained the necrotic lesions with infection structures of $R$. solani (Figure 1). Similar areas and amounts of tissues were excised from mock-inoculated controls (Figure 1). Tissues were flash-frozen with liquid nitrogen and stored at $-80^{\circ} \mathrm{C}$ for downstream applications.

\section{Optical and Fluorescence Microscopy}

The accumulation of cellular and extracellular ROS, primarily peroxide $\left(\mathrm{H}_{2} \mathrm{O}_{2}\right)$ during disease progression in tissues of infected potato and mock-inoculated was visualized following the method of Samsatly et al. (2018). Briefly, ROS detection in tissue samples from potato were incubated with $10 \mu \mathrm{M}$ of the fluorescent probe, $2^{\prime}, 7^{\prime}$-dichlorodihydrofluorescein diacetate $\left(\mathrm{H}_{2} \mathrm{DCF}-\mathrm{DA}\right)$ in $\mathrm{H}_{2} \mathrm{O}$ for $30 \mathrm{~min}$, followed by washing with prewarmed $\mathrm{H}_{2} \mathrm{O}$ to remove the non-internalized probe. For the detection of in situ hydrogen peroxide $\left(\mathrm{H}_{2} \mathrm{O}_{2}\right)$ accumulation, thin shavings of potato tissues of infected and mock-inoculated control were stained with 3,3'diaminobenzidine (DAB) followed by clearing with $15.1 \mathrm{M}$ of chloral hydrate solution. Samples were examined under Zeiss SteREO Discovery.V20 microscope (Carl Zeiss Canada Ltd., Toronto, ON, Canada). Fluorescence detection in plant tissues was read at an excitation wavelength of $470 \mathrm{~nm}$ using a GFP filter. Bright field microscopy was performed to monitor disease development and capture fungal infection cushions, and images were digitally documented with the Moticam 2300 digital camera (GENEQ Inc., Montreal, QC, Canada) for light microscopy.

\section{Quantification of Fungal Load in Infected Potato Sprouts}

The quantification of fungal load by quantitative QPCR is a reliable method to measure fungal biomass during infection especially in pathogens, such as $R$. solani that do not produce conidia (Baumgartner et al., 2010), and also to assess fungal load of necrotrophic pathogens in Arabidopsis (Gachon and Saindrenan, 2004). We have estimated $R$. solani DNA 


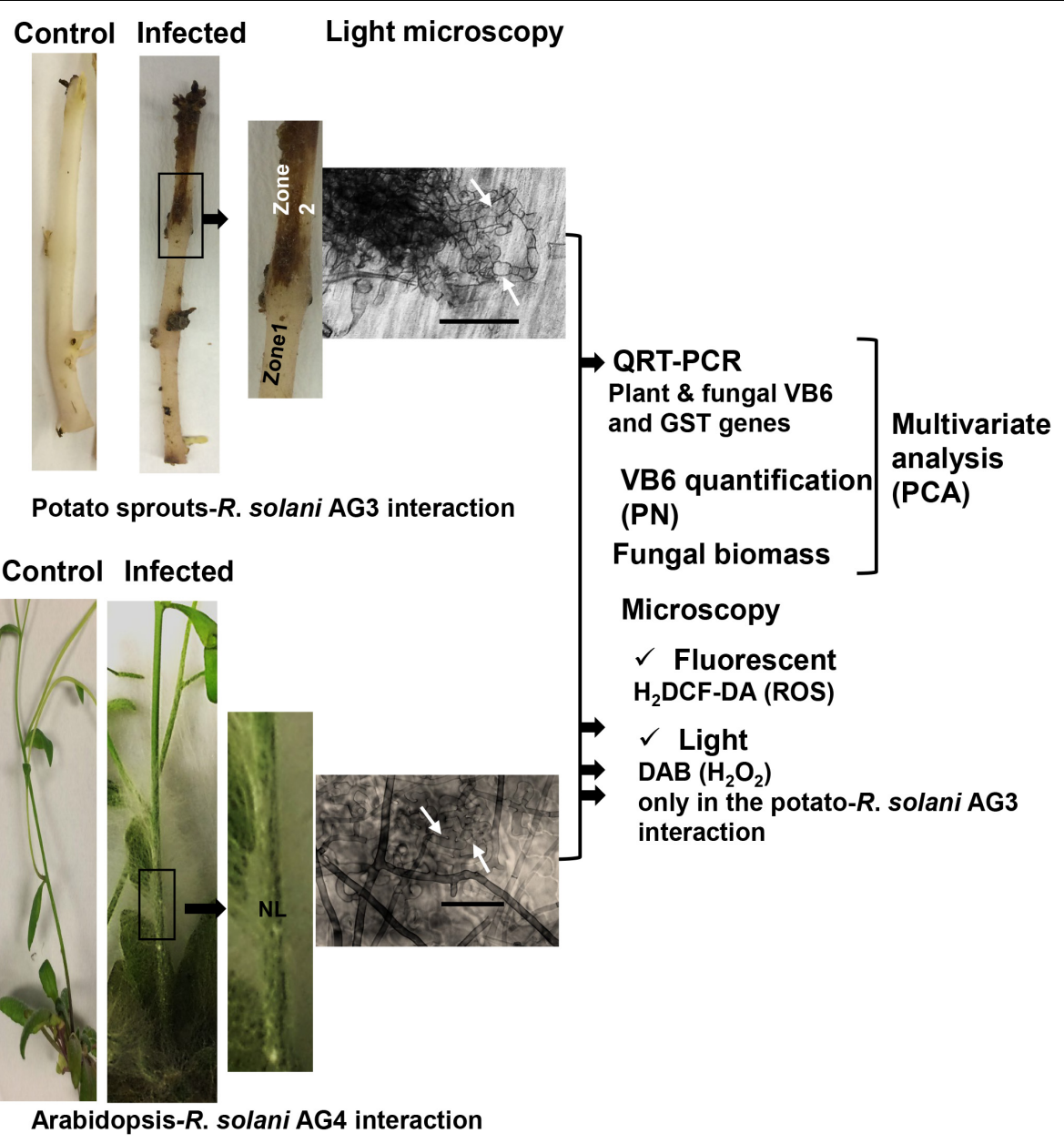

FIGURE 1 | Flow chart of the experimental set-up for disease development by $R$. solani AG3 on potato sprouts and by R. solani AG4 on Arabidposis. Sprouts and Arabidopsis lower stems were sandwiched between two PDA strips of a 3-day-old R. solani AG3 or AG4 cultures, respectively. Sprouts or Arabidopsis lower stems sandwiched with sterile PDA strips served as controls. Samples were taken at 120 HPI (Hour post-inoculation) (Potato-R. solani AG3 interaction) from adjacent surrounding areas (Zone 1) and necrotic lesions (Zone 2), and $72 \mathrm{HPI}$ (Arabidopsis-R. solani AG4 interaction) from infected lower stems of Arabidopsis. Corresponding segments were taken from controls. Typical initials of infection cushions with mycelial mass aggregates are clearly visible under the light microscope (white arrows). Transcriptional abundance of antioxidant genes, PN concentrations, and fungal biomass from both the plant and pathogen was analyzed in zones1 and 2 (Potato-R. solani AG3 interaction) and lower stem areas (Arabidopsis-R. solani AG4 interaction) followed by multivariate analysis (PCA). The two interactions were examined for ROS accumulation using fluorescent $\left(\mathrm{H}_{2} \mathrm{DCF}-\mathrm{DA}\right)$ and $\mathrm{DAB}$ (only the potato interaction) staining methods in control and infected sprouts or Arabidopsis lower stems. Zone1: tissue surrounding necrotic lesion. Zone 2, necrotic lesion; NL, necrotic lesion. Bar $=50 \mu \mathrm{m}$.

abundance of the glyceraldehyde-3-phosphatedehydrogenase gene in infected potato tissues of both cultivars by quantitative QPCR using the AG-3 specific primer pair set G3PDH-F/R (Table 1). The putative amplified products were purified using the QIAquick PCR Purification Kit (Qiagen), and sub-cloned in pDrive cloning vector (Qiagen). Absolute quantification of genomic gene copies was established from standard curves using six consecutive 10-fold dilutions of genomic DNA for $R$. solani AG3. Initial copies were calculated using the genomic size following the method of King et al. (2015). Total genomic DNA was isolated from $100 \mathrm{mg}$ of mock-inoculated control plant tissues and infected tissues (necrotic lesions) of potato and Arabidopsis using the DNeasy Plant Mini $\mathrm{Kit}^{\mathrm{TM}}$ (Qiagen, Toronto, ON, Canada). The concentration and purity of DNA were assessed by spectrophotometry with ND1000
(NanoDrop, Wilmington, Delaware). All Q-PCR reactions were carried on using Stratagene Mx3000 (Stratagene, Cedar Creek, United States).

Since fungal load is not a direct measure of disease progression, we digitally analyzed disease progression on sprout sections of both potato cultivars using the software ImageJ (Rasband, W.S., Image); U.S. National Institutes of Health, Bethesda, MD, United States) (1997-2012) ${ }^{1}$. The disease index was calculated as percent area of tissue infected by $R$. solani AG3 compared to the total area of tissue for Burbank and Chieftain cultivars using software ImageJ (Abd-El-Haliem, 2012; Stewart et al., 2016).

\footnotetext{
${ }^{1}$ http://imagej.nih.gov/ij/
} 
TABLE 1 | List of primers used in this study.

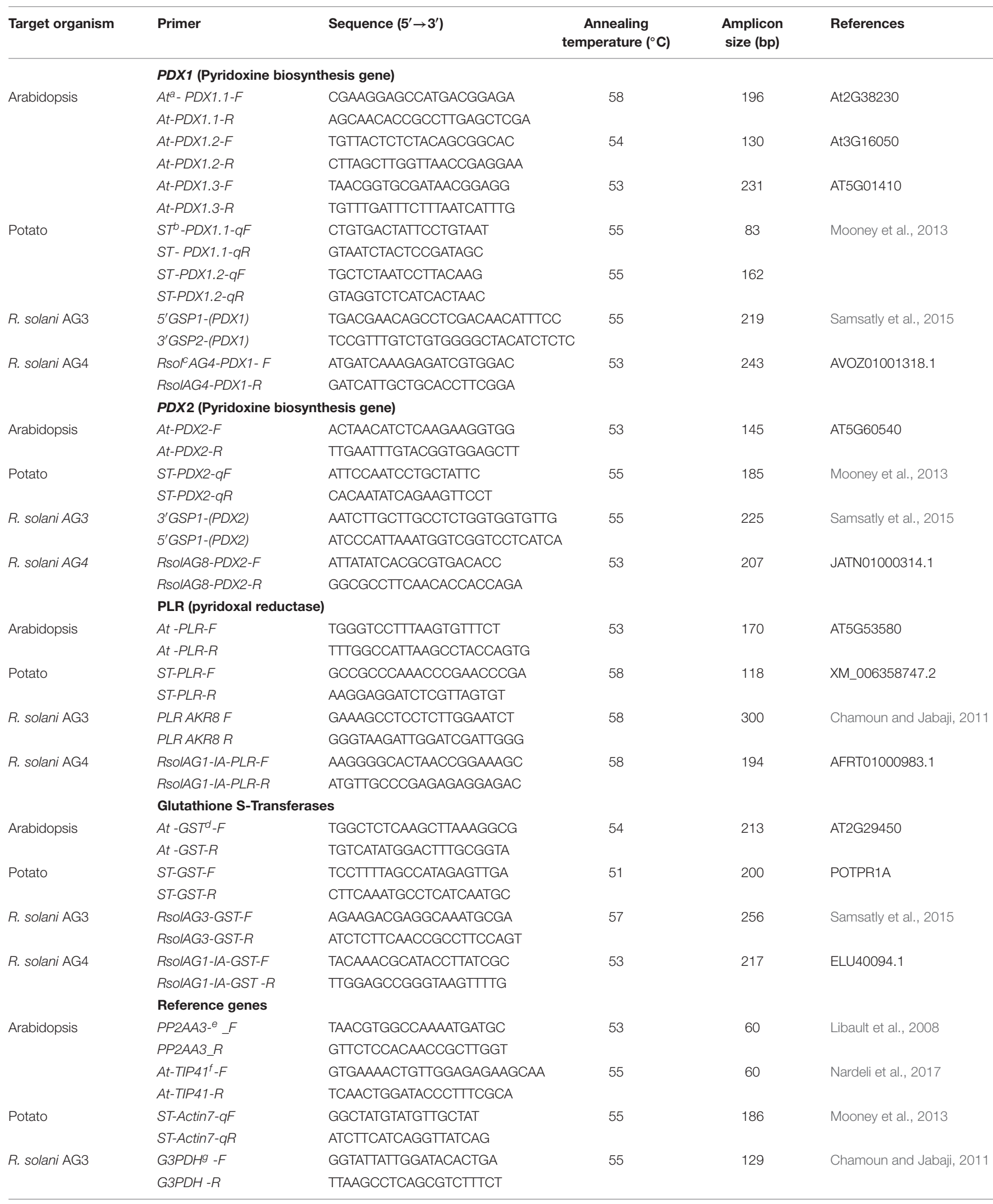


TABLE 1 | Continued

\begin{tabular}{|c|c|c|c|c|c|}
\hline Target organism & Primer & Sequence $\left(5^{\prime} \rightarrow 3^{\prime}\right)$ & $\begin{array}{c}\text { Annealing } \\
\text { temperature }\left({ }^{\circ} \mathrm{C}\right)\end{array}$ & $\begin{array}{l}\text { Amplicon } \\
\text { size (bp) }\end{array}$ & References \\
\hline \multirow[t]{3}{*}{ R. solani AG4 } & GM-RS-4h & CGGTTCATCTGCATTTACCTT & 55 & 88 & Johanson et al., 1998 \\
\hline & GM-RS3-R & AGTGTTATGCTTGGTTCCACT & & & \\
\hline & Genotyping primers & & & & \\
\hline \multirow[t]{3}{*}{ Arabidopsis } & SALK 086418-LP & AGCGAACCTCTCAACCTTCTC & 60 & $534-834$ & http://signal.salk.edu/ \\
\hline & $S A L K 086418-R P$ & TGTITAATCTTGACCGTCCG & & & tdnaprimers.2.html \\
\hline & SALK LB-1.3 & ATITGCCGATITCGGAAC & 60 & & \\
\hline
\end{tabular}

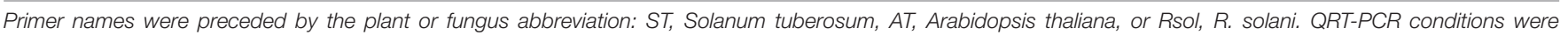

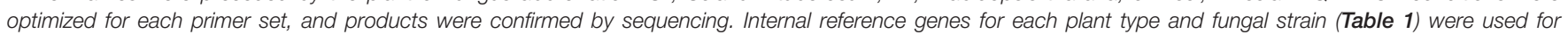

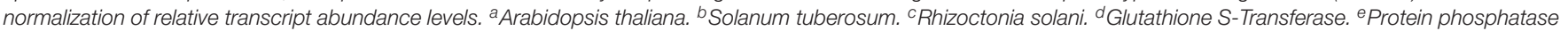
$2 A$ subunit A3. ${ }^{f}$ TIP41-like family protein. ${ }^{g}$ G3PDH: Glyceraldehyde-3-phosphate dehydrogenase. ${ }^{h}$ ITS1 of 5.8S rRNA.

\section{Vitamin B6 Analysis by LC-MS}

To determine whether the level of vitamin B6 was affected in infected tissues as compared to mock-inoculated controls, the vitamer pyridoxine (PN) was extracted from lyophilized inoculated and mock-inoculated control tissues of potato cultivars following the modified method of Denslow et al. (2005). Briefly, $0.1 \mathrm{~g}$ of tissues were ground in liquid nitrogen, mixed with $30 \mathrm{~mL} 0.44 \mathrm{~N} \mathrm{HCl}$, and autoclaved at $121^{\circ} \mathrm{C}$ for 2 h. pH was brought to 4.8 using sodium acetate, and each sample was de-glycosylated using fresh B-glucosidase $(5 \mathrm{mg}$ in $1 \mathrm{~mL} \mathrm{H}_{2} \mathrm{O}$ ) and de-phosphorylated with fresh acid phosphatase (75 mg in $2 \mathrm{~mL} \mathrm{H}_{2} \mathrm{O}$ ). Samples were added to flasks $(50 \mathrm{~mL}$ capacity) and incubated overnight in a $37^{\circ} \mathrm{C}$ incubator shaker at $70 \mathrm{rpm}$. The mixture in each flask was brought to $50 \mathrm{~mL}$ with deionized $\mathrm{H}_{2} \mathrm{O}$ and filtered through $0.22 \mu \mathrm{m}$ filters (MillexFG, Millipore, MA, United States). Samples were stored at $-20^{\circ} \mathrm{C}$ and all later steps of vitamin B6 analysis were done in dark conditions. Surrogate analog, $400 \mathrm{ng}$ of pyridoxine(methyl-d3) (Sigma-Aldrich, Oakville, Canada) (Table 2), was spiked before extraction in all samples. Procedural blanks were prepared in the same manner. Four samples were spiked with $400 \mathrm{ng}$ of PN (Sigma-Aldrich) to estimate the recovery rates of the method. Matrix effects were assessed by comparing the signal obtained from spiked extracts with PN standard and with the equivalent signal obtained from pure solvent standards.

TABLE 2 | Vitamin B6 vitamers used in the study and their description.

\begin{tabular}{lcccc}
\hline Vitamer & $\begin{array}{c}\mathbf{M w} \\
\mathbf{g} / \mathbf{m o l}\end{array}$ & $\begin{array}{c}{[\mathbf{M}+\mathbf{H}]^{+}} \\
\mathbf{m / z}\end{array}$ & $\begin{array}{c}\text { Empirical } \\
\text { Formula }\end{array}$ & $\begin{array}{c}\text { Retention time } \\
\text { (minute) }\end{array}$ \\
\hline Pyridoxine-(methyl-d3) & 172.1 & 173.10 & $\mathrm{C}_{8} \mathrm{D}_{3} \mathrm{H}_{8} \mathrm{NO}_{3}$ & 2.33 \\
& & & &
\end{tabular}

$\begin{array}{lllll}\text { Pyridoxine (PN) } & 169.1 & 170.08 & \mathrm{C}_{8} \mathrm{H}_{11} \mathrm{NO}_{3} & 2.33\end{array}$

Unless otherwise stated, VB6 concentrations refer to the amounts of the vitamer PN.

High-performance liquid chromatography coupled to quadrupole time-of-flight tandem mass spectrometry (HPLCQTOF-MS) analysis was performed using an Agilent 1290 Infinity LC System coupled to a 6540 Accurate-Mass QTOF System operated in the positive ionization mode (Agilent Technologies, Santa Clara, CA, United States). The separation was performed with a Poroshell EC-C18 Column $(3.0 \times 100 \mathrm{~mm}$, $2.7 \mu \mathrm{m}$, Agilent Technologies) fitted with an Infinity Lab Poroshell 120 pre-column $(3.0 \times 5 \mathrm{~mm}, 2.7 \mu \mathrm{m})$ in a thermostated column compartment set at $20^{\circ} \mathrm{C}$. HPLC grade solvents (water, methanol), as well as LC/MS grade of formic acid were all purchased from Fisher Chemical (Pittsburgh, PA, United States) (Supplementary Figure S1). The mobile phase consisted of water (A) and methanol (B), both containing $0.1 \%$ of formic acid. The HPLC gradient was as follows: 1-6 $\mathrm{min}$ (100\% A), 6-10 min (75\% $\mathrm{A}$ and $25 \% \mathrm{~B}), 10-12(100 \% \mathrm{~B}) \mathrm{min}, 12-12.01 \mathrm{~min}(100 \%$ B), $12.01-14 \mathrm{~min}(100 \% \mathrm{~B})$. The flow rate was $0.5 \mathrm{~mL} \cdot \mathrm{min}^{-1}$ with an injection volume of $2.00 \mu \mathrm{L}$. MS scans $(\mathrm{m} / z$ 50-500) were completed at a scan rate of 4 spectra/s. Prior to analysis, the QTOF was tuned (mass accuracy $<1 \mathrm{ppm}$ ), and mass accuracy was maintained throughout the batch using the continuous infusion of a reference mass mix. Compound identification was based on mass spectra and retention times of pure VB6 analytical standards (Table 2). Target analytes were quantified using a 6-points calibration range $\left(10-400 \mathrm{ng} \cdot \mathrm{mL}^{-1}\right)$ based on the extracted chromatogram for their specific protonated molecular ion $[\mathrm{M}+\mathrm{H}]^{+}$. Concentrations were calculated from the relative response versus the mass-labeled $\mathrm{PN}$ analog.

\section{RNA Extraction, and Quantitative RT-PCR}

Total RNA was extracted from flash-frozen pulverized tissues (100 mg) using TRIZOL (Generay Biotech, Shanghai, China) following the manufacturer's instructions. RNA (500 ng) was reverse-transcribed with the Quantitect Reverse transcriptase $\mathrm{kit}^{\mathrm{TM}}$ (Qiagen) according to the manufacturer's protocols. QRT-PCR analyses were conducted on fungal and plant target antioxidant genes (Table 1). Primers for fungal VB6 and GST encoding genes were designed as previously described (Samsatly et al., 2018). Internal reference genes and potato VB6 and GST encoding genes were synthesized based on 
published sequenced primers (Table 1). QRT-PCR conditions were optimized for each primer set (Table 1), and putative products were confirmed by sequencing. Reverse transcription PCR assays were performed on three biological replicates and two technical replicates. QRT-PCR assays were conducted on fungal and plant target antioxidant genes encoding GST, the de novo VB6 biosynthesis genes; a synthase (PDX1) and a glutaminase (PDX2), and the VB6 salvage pathway encoding gene, Pyridoxal Reductase (PLR) and appropriate internal reference genes (Table 1) using Stratagene Mx3000 (Stratagene, Cedar Creek, United States). PCR assay conditions were performed using suitable annealing temperature for each primer pair (Table 1) with the following conditions: Each 20 $\mu \mathrm{L}$ reaction contained 1X SsoAdvanced Universal SYBR Green Supermix (Bio-Rad Laboratories Ltd.), $0.16 \mu \mathrm{M}$ each primer, and $500 \mathrm{ng}$ cDNA. The thermocycling profile used an initial denaturation at $98^{\circ} \mathrm{C}$ for $2 \mathrm{~min}$, followed by 35 or 40 cycles of denaturation at $98^{\circ} \mathrm{C}$ for $15 \mathrm{~s}$, annealing for $30 \mathrm{~s}$ at the appropriate primer temperature and extension at $72^{\circ} \mathrm{C}$ for $30 \mathrm{~s}$, followed by a dissociation curve analysis. At every run, routine negative and positive controls were performed. The relative transcript abundance levels of the plant and fungal-derived genes were normalized against their respective reference genes according to the method reported by Zhoa and Fernald (2005).

\section{Arabidopsis Pathogenicity Experiments}

Seeds of Arabidopsis thaliana wild type, ecotype Col-0 and pdx1.3 mutants (At5g01410- SALK 086418C) were obtained from Arabidopsis Biological Resource Center (Ohio State University, Columbus; (Alonso et al., 2003; Titiz et al., 2006). PCR-based genotyping was carried out for SALK 086418C lines to screen for homozygous plants. Gene-specific primers SALK 086418-LP/RP and T-DNA primers SALK LB-1.3 (Table 1) were included following the T-DNA Express Web site $^{2}$. Plants homozygous for PDX1.3 mutation were used for downstream applications.

Seeds were surface sterilized by immersing them in $70 \%$ ethanol for $45 \mathrm{~s}$, followed by $1.3 \%$ bleach for $3 \mathrm{~min}$ and rinsed five times with sterile water. Sterile seeds were stratified at $4^{\circ} \mathrm{C}$ for 5 days in the dark prior to planting. Seeds were sown in Square Pots $10 \times 10 \times 11 \mathrm{~cm} 0.69 \mathrm{~L}$ containing AgroMix G10 (Fafard Ltd.) and sand (1:1, v/v) with one seed per pot and placed in a growth cabinet with a $16 / 8 \mathrm{~h}$ light/dark photoperiod and 100 $\mu \mathrm{mol} / \mathrm{ms}$ of light at $22^{\circ} \mathrm{C} / 19^{\circ} \mathrm{C}$, respectively, with $60 \%$ relative humidity. Eight weeks-old seedlings were used for disease assays.

Arabidopsis seedlings of wild type and mutant ecotypes were carefully removed from the potting mix, and the roots were rinsed with distilled water to remove soil particles. Ten seedlings of Arabidopsis wild type ecotype Col-0 and $p d x 1.3$ mutants (At5g01410, SALK 086418C) were placed in sterile Pyrex trays as described above and sandwiched with two strips of PDA strips $(0.5 \mathrm{~cm} \times 8 \mathrm{~cm})$ of a 3 -day-old $R$. solani AG4 isolate A76 culture covering the crown, lower stem and part of the roots. Mock-inoculated controls were sandwiched with sterile PDA strips. There were three biological replicates per treatment and

${ }^{2}$ http://signal.salk.edu/tdnaprimers.2.html each treatment replicate consisted of 10 Arabidopsis seedlings. Progression of infection was determined at 72 HPI. One zone was sampled which consists of necrotic lesions developing at the crown area and lower stem parts. Similar areas and amounts of tissues were excised from mock-inoculated controls.

RNA isolation, cDNA synthesis, and qPCR reactions were carried out as described above for potato. Primer sets were designed for Arabidopsis based on sequences from NCBI, and were checked for specificity to amplify only their target gene (Table 1). Specific primers used for the amplification of VB6, GST encoding genes of Arabidopsis and of R. solani AG4 were designed as previously described (Samsatly et al., 2018). Internal reference genes for Arabidopsis and $R$. solani AG4 (Table 1) were used for normalization of relative transcript abundance levels.

The fungal load of $R$. solani AG4 was estimated in infected tissues of Arabidopsis wild type and pdx1.3 mutant line, by amplifying the gDNA using the primer pair set RsolAG4PDX1F/R in Q-PCR assays (Table 1). PCR assays were performed as described above for potato. Optical and fluorescence microscopy to detect ROS accumulation, primarily superoxide $\left(\mathrm{O}^{-}{ }_{2}\right)$ and hydrogen peroxide $\left(\mathrm{H}_{2} \mathrm{O}_{2}\right)$ during disease progression in the wild type and mutant lines of Arabidopsis infected or not with $R$. solani AG4 was visualized by $\mathrm{H}_{2}$ DCF-DA and staining method following the protocol described above.

\section{Statistical Analyses}

Two-way analysis of variance (ANOVA) and the least significant differences (LSD) at $P<0.05$ were used to compare the values of the relative transcript abundance, VB6 concentrations and fungal biomass between the treatments and the controls using the SPSS statistical package v. 22.0 (IBM Corp., Armonk, NY, United States). Transcript changes were considered statistically and biologically significant if $P<0.05$ and fold changes were $>+1.5$ or $>-1.5$.

In order to understand the simultaneous relationships among the relative abundance of host and fungal-derived antioxidant genes, VB6 concentrations and fungal biomass, and to predict the effect and impact of a change in one variable will have on other variables, a multivariate analysis of the data was performed on potato-R. solani and Arabidopsis-R. solani interactions (Figure 1) using the SIMAC-P + v12.0 (Umetrics, MKS Instruments Inc., Andover, MA, United States). The data matrix for potato$R$. solani comprised of biological replicates of control fungal tissues, mock-inoculated control plant tissues, plant tissues of zone 1 , and plant tissue of zone 2 (columns; $\mathrm{X}$ variables), and the variables for relative transcript abundance of antioxidant genes, VB6 concentration, fungal biomass (rows; Y variables). Data were acquired from the analysis of relative transcript abundance, PN concentrations, and fungal biomass for potato sprouts- $R$. solani AG3 (10 antioxidant genes) [21 rows $\times 12$ columns]. The data matrix for Arabidopsis- $R$. solani consisted of biological replicates of control fungal tissues, mock-inoculated control plant tissues, plant tissues with necrotic lesions (columns; $\mathrm{X}$ variables), and the variables for relative transcript abundance of antioxidant genes, VB6 concentrations, fungal biomass (rows; Y 
variables). Data were obtained from the analysis of 11 antioxidant genes ( 11 antioxidant genes) [ 15 rows $\times 13$ columns].

The principal component analysis (PCA) was performed to determine which of the genes were most affected, and also to check if they were linearly correlated with VB6 concentration and fungal biomass in each interaction. Therefore, PCA loading coefficient plots (coupled with $p$-values) and loading biplots for the effect of VB6 concentration, fungal biomass, and the relative transcript abundance of genes in each tissue type were built for the visualization of correlations between the $\mathrm{X}$ and $\mathrm{Y}$ variables using the $\mathrm{pc}$ (corr) (i.e., correlation scaled loadings of the correlation between $\mathrm{Y}$ variables and $\mathrm{X}$ scores based on the variable importance of $\mathrm{X}$ as scores and loadings) setting in SIMCA-P+. Mean-centering and UV scaling were used for data normalization.

\section{RESULTS}

\section{Distinct Patterns of VB6 Gene Expression, Differential PN Concentration, and Fungal Biomass Among Potato Cultivars and Arabidopsis Lines}

To explore sources of variance within transcript levels, VB6 concentrations (measured as vitamer $\mathrm{PN}$ ) and fungal load expressed as biomass, we used PCA. The analysis revealed tight groups with no outliers $(P<0.05)$ (Supplementary Figure S3). The principal components (PCs) which are the PCA axes are identified (Figures $\mathbf{2 A}, \mathbf{C}, \mathbf{D}, \mathbf{E}$ ). The amount of correlation between the expression levels of a gene, VB6 concentration and fungal biomass and a PC is designated by the extent of their loadings as indicated on the PC axes (Figure 2 and Supplementary Tables S1, S2). This approach identifies genes, VB6 concentration and fungal biomass having expression levels that are highly positively or negatively correlated with a given PC.

The strength of the correlations is pathosystem-dependent (Figure 2). In potato-R. solani AG3, PC1 and PC2 explained the majority of the variance in the dataset with tight grouping that led to the separation between the treatments (i.e., infected and control). Also, selected antioxidant genes were highly linked with the interaction zone as shown in the PCA-loading biplot of the potato- $R$. solani AG3 interaction (Figure 2A). In Arabidopsis $-R$. solani interaction, only PC2 and PC3 but not PC1 explained most of the variance in the dataset (Figures 2CE). Interestingly, in both plant-fungus interactions, the PCA analysis showed that both fungal biomass and VB6 concentration contributed significantly to disease development (Figures 2B,F and Supplementary Tables S1, S2).

\section{Accumulation of ROS in R. solani Mycelia and Potato Plant Tissues Is Indicative of Oxidative Stress}

Detection of ROS in the fungal hyphae and plant tissues was made possible by fluorescent $\mathrm{H}_{2}$ DCF-DA and non-fluorescent DAB methods in Potato-R. solani. Tissues of mock-inoculated control of potato cv. Russet Burbank and Chieftain sprouts examined under bright field (Figures 3A,G), displayed no green fluorescence using the $\mathrm{H}_{2}$ DCF-DA probe (Figures $3 \mathbf{B}, \mathbf{C}, \mathbf{H}, \mathbf{I}$ ). Under bright field (Figures 3D,J) infected potato cV. Russet Burbank and Chieftain sprouts with $R$. solani displayed intense green fluorescence (Figures 3E,F,K,L). The generation of ROS, primarily $\mathrm{H}_{2} \mathrm{O}_{2}$ and superoxide $\left(\mathrm{O}^{-}{ }_{2}\right)$ in response to $R$. solani was assayed in situ using DAB staining. Tissues of infected potato cv. Russet Burbank sprouts displayed more brown precipitate pattern when compared to potato $\mathrm{cv}$. Chieftain at necrotic and surrounding areas (Figures 3N,P, respectively). Digitally analyzed images of the same areas, using ImageJ software, resulted in higher disease score of $50.4 \%$ in Russet Burbank versus $32.4 \%$ in Chieftain. Control uninfected tissues did not show any browning (Figures $\mathbf{3 M}, \mathbf{O}$, respectively).

\section{Potato cv. Russet Burbank Had More Fungal Load Than Potato cv. Chieftain}

Analysis of the transcript for the $R$. solani G3PDH gene as an indicator of fungal load in planta confirmed that potato cv. Russet Burbank plants had more fungal biomass than the moderately tolerant potato cv. Chieftain. Potato cv. Russet Burbank displayed a statistically higher copy number of fungal gDNA compared to the moderately tolerant cv. Chieftain by 2.9-fold (Figure 4A), indicating that fungal biomass of the virulent strain 114 was closely correlated with stolon interaction, high loading coefficient values of fungal biomass were observed (Supplementary Tables S1, S2 and Figures 2B,F).

\section{Enhanced VB6 Content Has Only Limited Impact on Stress Performance in Potato Cultivars}

VB6 analysis revealed strong recovery rates of $98.5 \pm 1.5 \%$ for pyridoxine (PN). The method of detection limit was $0.124 \mu \mathrm{g}^{\mathrm{g}} \mathrm{g}^{-1}$ with a matrix effect of $102.41 \pm 7.4 \%$. Vitamin B6 (PN) content in plant tissues before and after inoculation with $R$. solani AG3 were linked with potato tissues of both cultivars based on loading coefficient values (Supplementary Table S1 and Figures 2A,E). Without pathogen inoculation, the constitutive levels of VB6 were significantly $(P<0.05)$ higher in the susceptible potato $\mathrm{cv}$. Russet Burbank (1.6-fold) compared to the tolerant potato $\mathrm{cv}$. Chieftain. After infection, VB6 content in infected potato tissues increased by 1.7 -fold $(P<0.05)$ in potato $\mathrm{cv}$. Chieftain, whereas in potato cv. Russet Burbank, the VB6 content slightly increased by1.4-fold change (Figure 4B).

\section{The Interaction Zone Shows Significant Shifts of Potato-Derived VB6 and GST Antioxidant Genes, Impacting Disease Resistance Against $R$. solani}

The transcript abundance of potato antioxidant genes, STGST (p, $65 \%$ ), and the VB6 de novo STPDX1.1 (p, 63\%) were positively correlated with potato cultivar and with the interaction zone sampled (i.e., zone 1 versus zone2). In the susceptible potato $\mathrm{cv}$. Russet Burbank, a significant fold increase in relative transcript 

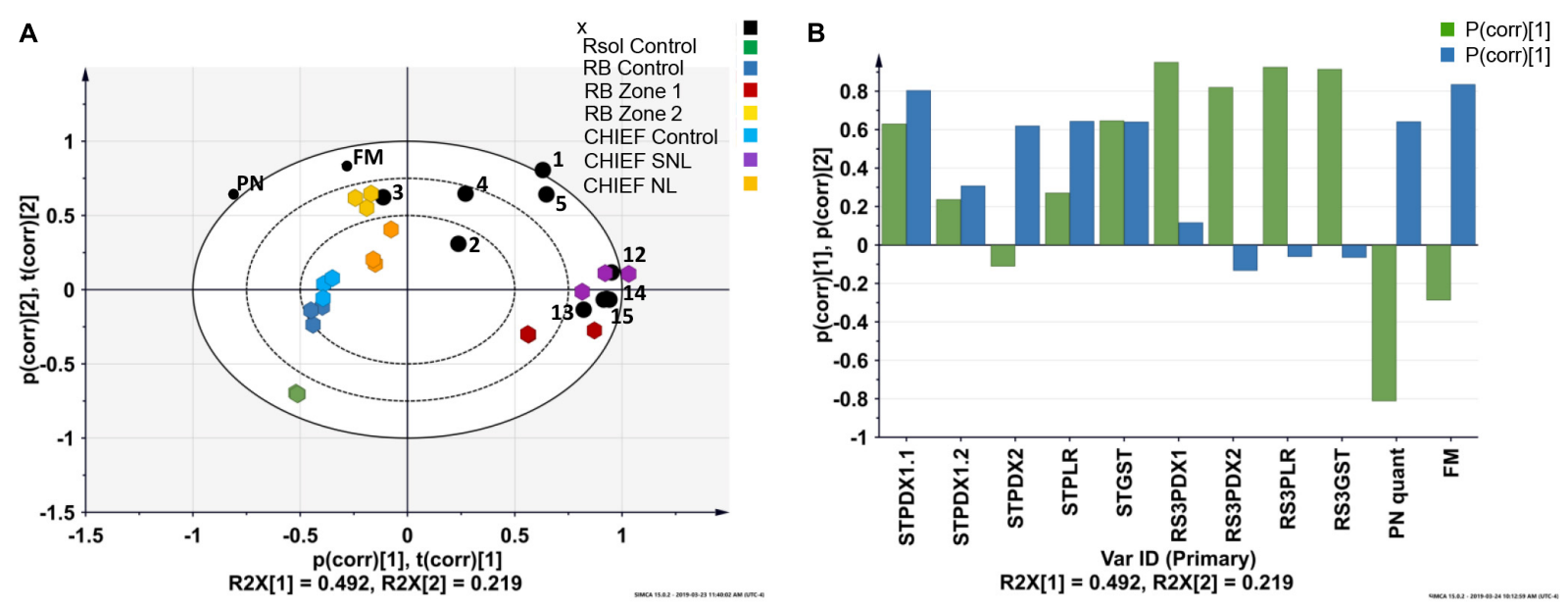

C

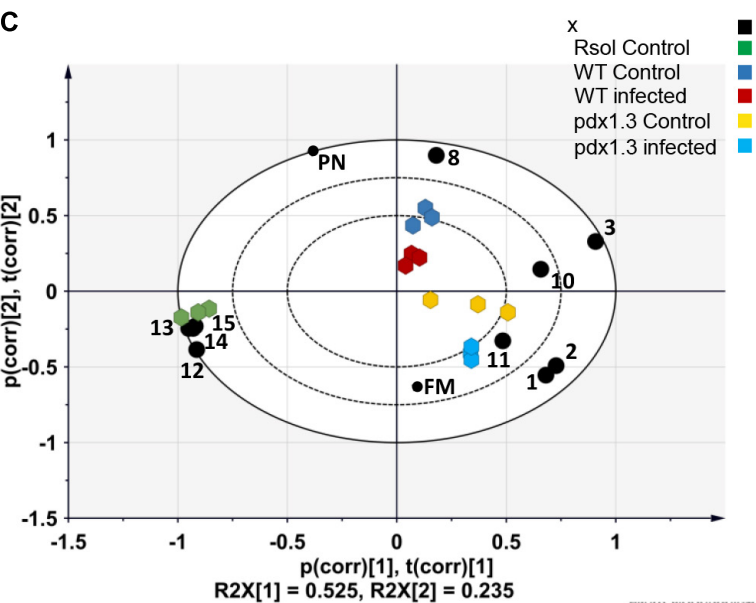

D

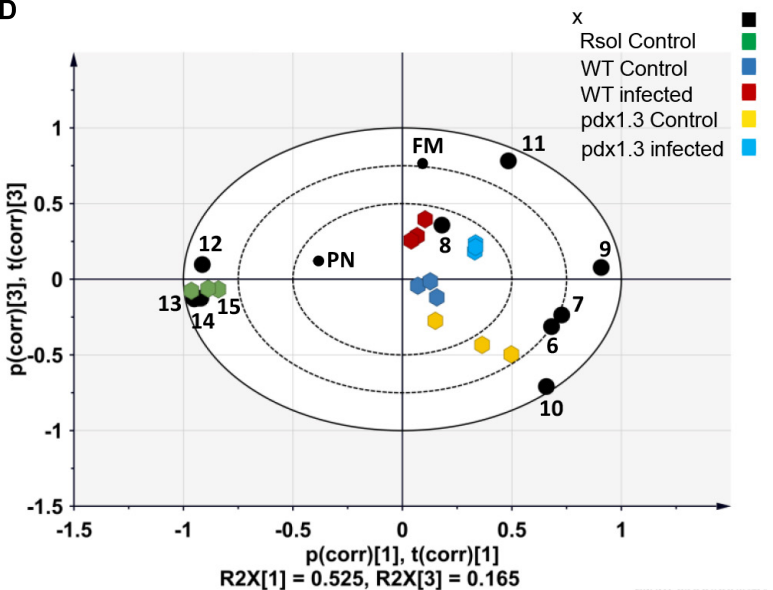

E
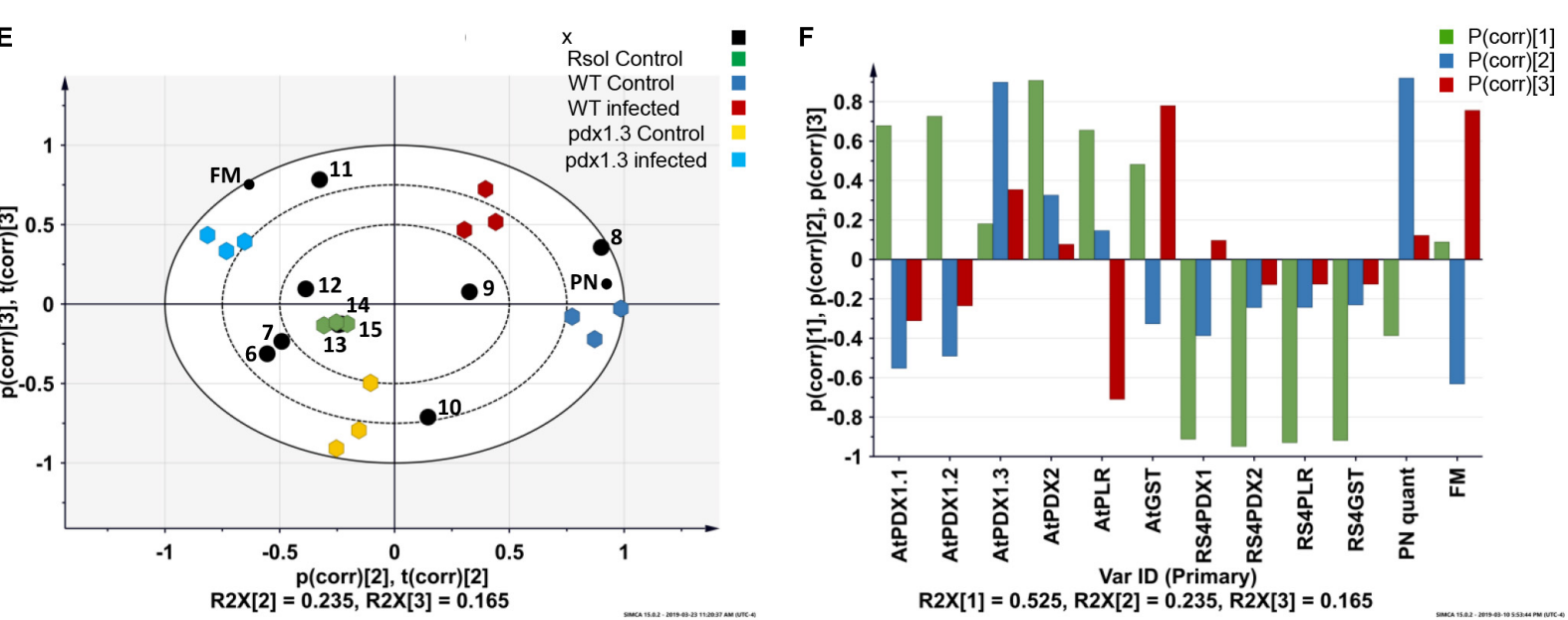

FIGURE 2 | Principal component analysis (PCA) loading biplots for the effect of transcriptional abundance of antioxidant genes, PN concentrations, and fungal biomass on control, infected tissues in (A) potato sprouts-R. solani AG3 interaction, and (C,D,E) and Arabidopsis-R. solani AG4 interaction $(P<0.05)$. Principal component analysis (PCA) loading coefficient plots for the effect of transcriptional abundance of antioxidant genes, PN concentrations, and fungal biomass on control, infected tissues in (B) potato sprouts-R. solani AG3, and (F) Arabidopsis-R. solani AG4. The scaled loading vectors pc (corr) and $t$ (corr) are displayed for the first and the second component for potato- $R$. solani AG3 interaction and the first, the second, and the third component for Arabidopsis-R. solani AG4 interaction. Outer ellipses represent the Hotelling's $T^{2}$ at a 95\% confidence interval. $R^{2} X$ represents the fraction of the sum of squares of the two principal components. ST, Solanum tuberosum; AT, Arabidopsis thaliana; RS3, R. solani AG3; RS4, R. solani AG4. Black circle represents genes. $1=$ STPDX1.1, $2=$ STPDX1.2, $3=$ STPDX2, $4=$ STPLR, $5=$ STGST, $6=$ ATPDX1.1, $7=$ ATPDX1.2, $8=$ ATPDX1.3, $9=$ ATPDX2, $10=$ ATPLR, $11=$ ATGST, $12=$ RsolPDX1, $13=$ RsolPDX2, $14=$ RsolPLR, 15 = RsolGST. FM, fungal biomass; PN, vitamin B6 (pyridoxine) concentration; RB, Russet Burbank; CHIEF, Chieftain; Zone1, Tissue surrounding necrotic lesion; Zone 2, Necrotic lesion; Rsol, R. solani AG3 in the potato interaction and R. solani AG4 in the Arabidopsis interaction; WT, wild type. 

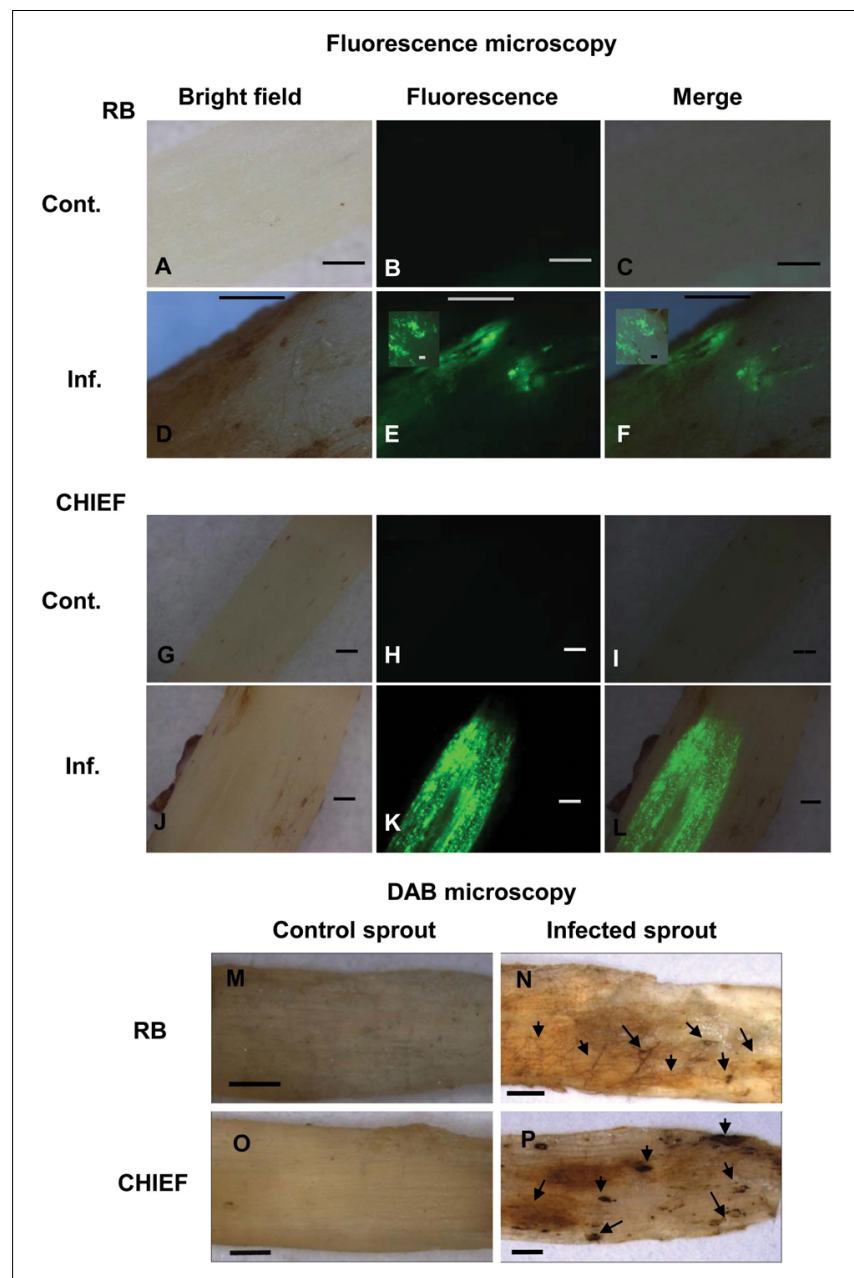

FIGURE 3 | Intracellular production of ROS (A-L) and detection of $\mathrm{H}_{2} \mathrm{O}_{2}$ accumulation using DAB staining (M-P) during disease development in the potato- $R$. solani AG3 interaction. ROS production was visualized using $\mathrm{H}_{2}$ DCF-DA in control and infected potato sprouts. Control S. tuberosum sprouts, with no evidence of endogenous ROS (A,O). Infected tissues during disease development (D-F,J-L). $\mathrm{H}_{2} \mathrm{O}_{2}$ accumulation was visualized by DAB staining in control and infected potato sprouts. Arrows indicate dark brown precipitate developed at necrotic and surrounding areas $\mathbf{( N , P )}$. Control potato sprouts $(\mathbf{M}, \mathbf{O})$ with no evidence of endogenous $\mathrm{H}_{2} \mathrm{O}_{2}$ at 120 HPT. R. solani mycelia and $\mathrm{S}$. tuberosum sprout (N,P) with $\mathrm{H}_{2} \mathrm{O}_{2}$ accumulation at 120 HPT. RB, Russet Burbank; CHIEF, Chieftain; Cont., control; Inf., infected. Bar $=1 \mathrm{~mm}$.

abundance of STPDX1.1 (1.97-fold) and STGST (4.68-fold) was observed in zone 2 . In the tolerant potato cv. Chieftain, an opposite trend was observed. The surrounding tissues in zone 1 significantly expressed fold increase of STPDX1.1 (1.62fold) and STGST (7.86-fold) (Figure 5). Gene expression of STPDX2 was tightly linked to potato cultivar. A strong activation of STPDX2 in tissues of zone 2 of potato cv. Russet Burbank with a 3.34-fold increase, and a downregulation in zone 1 and zone 2 in potato cv. Chieftain (-2.94 and -3.35fold decrease, respectively). Despite the low loading value ( $\mathrm{p}$, $27 \%$ ), the VB6 salvage pathways STPLR showed a significant upregulation of the relative transcript abundance in zones 1 and 2 in both potato cultivars, but with higher levels in potato cv. Chieftain (Figure 5). STPDX1.2, the non-catalytic homolog, showed a biologically significant down-regulation in both cultivars (up to a maximum of -3.01-fold decrease in cv. Russet Burbank) except in potato cv. Chieftain, the relative transcript abundance in zone 1 remained similar to the control tissues (1.14-fold) (Figure 5).

\section{Expression of Fungal-Derived VB6 Biosynthetic and GST Antioxidant Genes Are Not Correlated With Basal Resistance of Potato Cultivars but Are Tissue Zone-Driven}

A notable upregulation of the fungal-derived genes encoding the vitamin B6 de novo and salvage pathway genes, and GST was observed during disease development of $R$. solani AG3 on sprouts of cv. Russet Burkank and Chieftain potato cultivars. Fungal genes with high loadings for PC1 were noted for RsolAG3PDX1, RsolAG3PDX2, RsolAG3PLR, and RsolAG3GST (Supplementary Table S1) and were abundantly expressed and tightly linked with interaction zone 1 (i.e., tissues of surrounding areas of necrotic lesions of both potato cultivars) (Figures 2A,B). Significant fold increase of transcript abundance of these genes ranged from a minimum of 3.60 for RsolSG3GST to a maximum of 13.53 for RsolAG3PDX2 (Figure 5).

\section{Confirmation of Arabidopsis Null Mutants and Presence of ROS During the Interaction With $R$. solani}

To explore the possibility of the role of VB6 in plant disease resistance, we have compared the expression of fungalderived and plant-derived genes of Arabidopsis wild type Col-0 and $p d x 1.3$ mutants. Homozygous mutant plants were identified by genotyping with gene-specific primers flanking the insertion sites (Supplementary Figure S2). RT-PCR analysis revealed that no ATPDX1.3 transcripts were detected in the $p d x 1.3$ mutant plants (Figure 8). These data indicate that the pdx1.3 are null mutants of the ATPDX1.3 genes. These homozygous mutant lines were used for the further experiments as described below.

Tissues of mock-inoculated control of Arabidopsis wild type Col-0 and pdx1.3 mutant lower stems (Figures 6B,C,H,I) did not display any green fluorescence. An intense green fluorescence was detected in the tissues of Arabidopsis wild type and pdx1.3 mutant lower stems (Figures 6E,F,K,L), which supports the presence of oxidative stress during the interaction.

\section{The pdx1.3 Arabidopsis Mutants Showed More Susceptibility to R. solani Coined With Lower Amounts of VB6}

Arabidopsis $p d x 1.3$ plants were more susceptible to $R$. solani infections than the Arabidopsis wild type Col-0. The stems of the $p d x 1.3$ mutant Arabidopsis lines had significantly higher fungal load, expressed as gDNA copy number of A76 strain than that in the wild type plants by 1.80 -fold (Figure 7A). Prior to infection, the 

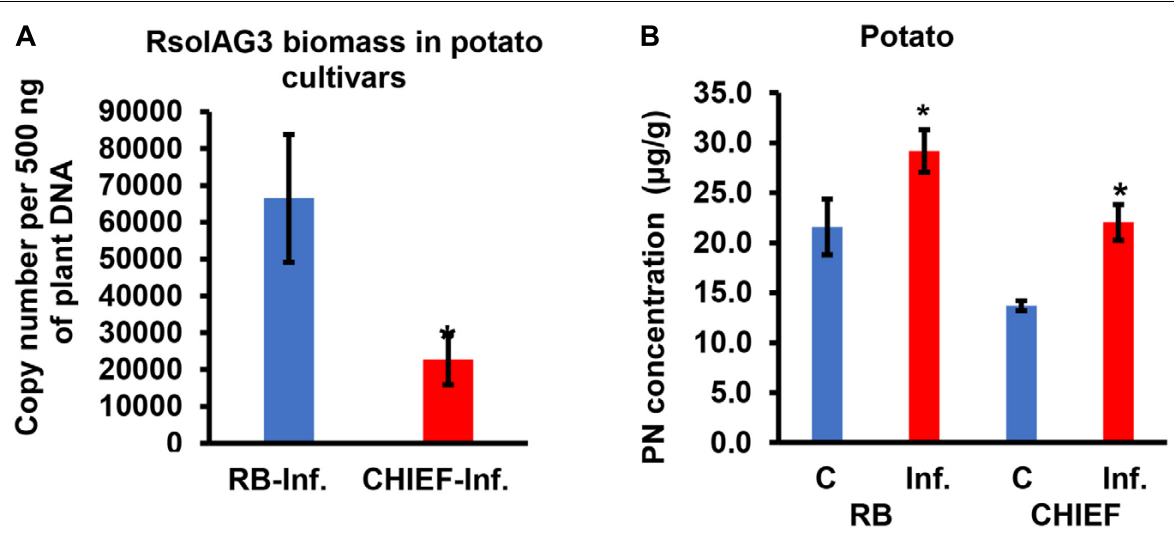

FIGURE 4 | Quantification of fungal gDNA (A) and concentration ( $\mu \mathrm{g} \mathrm{g}^{-1}$ ) of pyridoxine (PN) (B) in infected potato sprouts of two cultivars (RB and CHIEF). Fungal gDNA was measured using real-time quantitative PCR with $500 \mathrm{ng}$ of plant samples. Asterisk indicates significant relative transcript abundance ratios between the control and the infected tissues using least significant difference (LSD) test $(P<0.05)$. RB, Russet Burbank; CHIEF, Chieftain; C, control; Inf., infected.

constitutive VB6 content in Arabidopsis wild type was significantly higher $(P<0.05)$ by 3.31 -fold compared to $p d x 1.3$ mutant line. After infection a drop in the VB6 levels in infected tissues of Arabidopsis wild type (1.6fold decrease) was observed and no change occurred in the pdx1.3 mutant line (Figure 7B). Due to heavy infections and tissue maceration, digital analysis of infected tissues was not performed.

\section{Arabidopsis Vitamin B6 Genes and ATGST Mark a Potentially Adequate Defense Response During Disease Development}

The VB6 biosynthesis gene ATPDX1.3 is tightly linked with disease development based on coefficient loading values (Supplementary Table S2 and Figure 2F). After infection, levels of ATPDX1.3 transcripts were similar to those in the control of the wild type. No transcripts were detected in the pdx1.3 mutant lines. As expected, higher transcript levels of ATPDX1.1 (5.68 and 6.52 fold increases) and ATPDX1.2 (2.19 and 11.89 fold increases) were found in both control and infected tissues of the pdx1.3 mutant lines compared to the wild type decreases (Figure 8). Interestingly, the relative transcript abundance for ATPDX1.2 in the wild type infected tissues showed a significant 4.33 -fold decrease in comparison to the control (Figure 8). The plant-derived VB6 salvage pathway gene ATPLR and the antioxidant ATGST gene had a significant role in Arabidopsis-R. solani AG4 interaction as estimated by the strong loading coefficient values (Supplementary Table S2). Expression profile patterns of ATPLR was down-regulated while expression of ATGST was induced in both the wild type and the pdx1.3 mutants. Fungal-derived vitamin B6 genes and GST were suppressed during the disease development of $R$. solani AG4 on Arabidopsis. Only RsolAG4PDX1 was detected in the plant-infected tissues of both the wild type and the pdx1.3 mutant (Figure 8).

\section{DISCUSSION}

During disease development in plants, both the host and pathogen deploy a tight control and regulation of ROS production where the latter can function as a signaling factor leading to more fungal spread or suppression by the host defense machinery (Barna et al., 2012; Foley et al., 2016). This is reflected by unique differential expression of the antioxidant genes, including VB6 for different pathosystems. In this study, we compared the differential co-expression patterns of fungal and host VB6 and GST genes across the two potato cultivars.

This research further supports our previous findings (Samsatly et al., 2018) that both the pathogen and the host employ unique expression strategies in the necrotic lesion and in the surrounding tissue. The co-expression and accumulation of plant and pathogen vitamin B6 and other antioxidant genes in potato cultivars might be critical for ROS management and disease development and pathogenicity. To further study the factors governing the tight balance of ROS and the role of VB6, we investigated in this current work whether different potato cultivars containing variable amounts of vitamin B6 (Mooney et al., 2013) exhibit differential degrees of susceptibility to $R$. solani AG3. The experimental set-up described in this study provides further support to our previous findings (Samsatly et al., 2018) that both the pathogen and the host employ unique expression strategies of VB6 and GST antioxidant genes in the bordering tissue (zone 1) and in the necrotic tissue (zone 2). The use of multivariate analysis enabled us to draw meaningful biological associations of gene expression of VB6 biosynthetic pathways, GST antioxidant genes, VB6 content, and fungal biomass with potato genotypes exhibiting different degrees of susceptibility to $R$. solani. Our assumption that potato genotypes having different susceptibility background to $R$. solani would express unique VB6 and GST antioxidant genes profiles is established.

In the susceptible potato cv. Russett Burbank, the de novo VB6 biosynthetic genes STPDX1.1, STPDX2, STGST, and the VB6 salvage gene STPLR are upregulated in necrotic tissues (zone 2) 


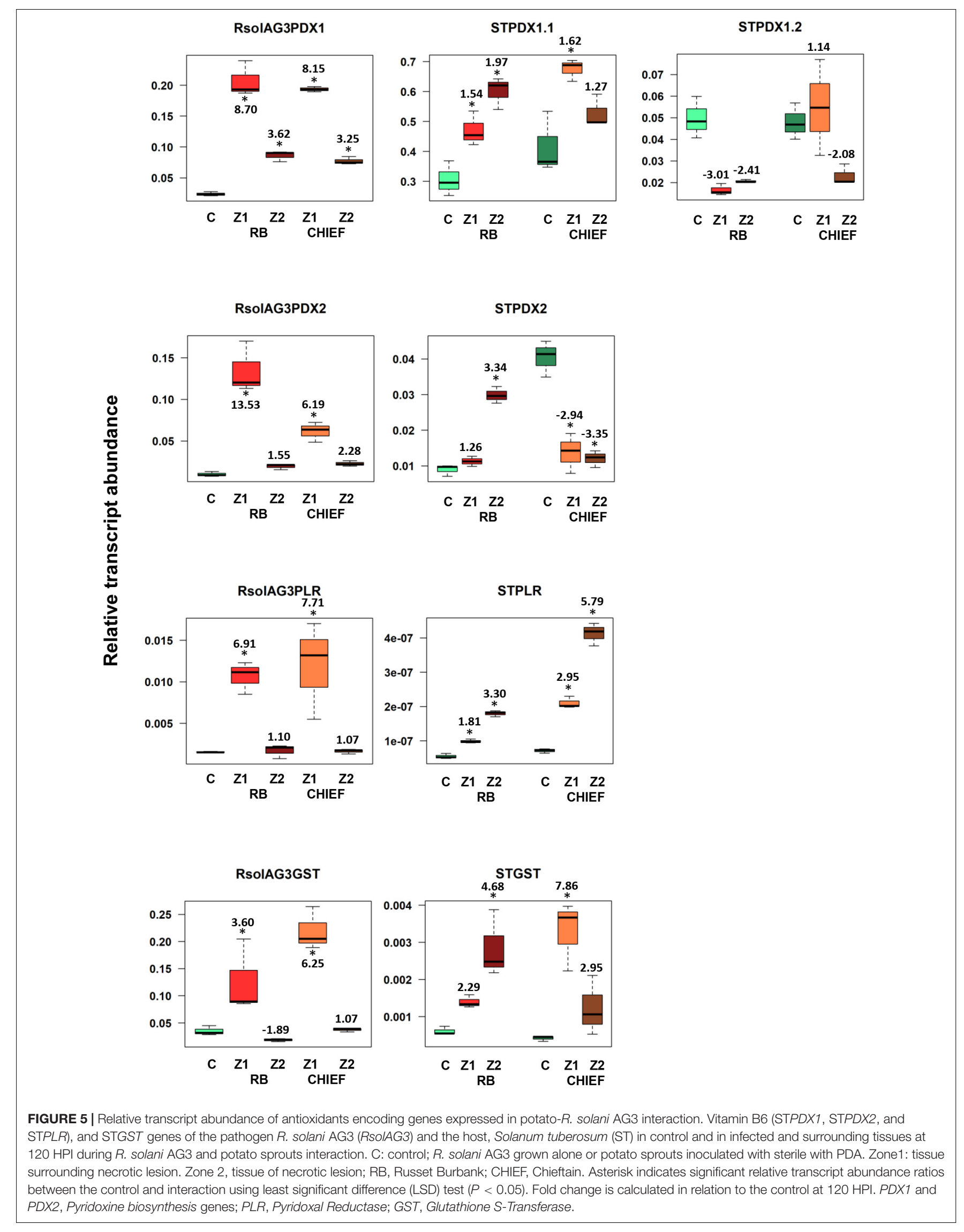




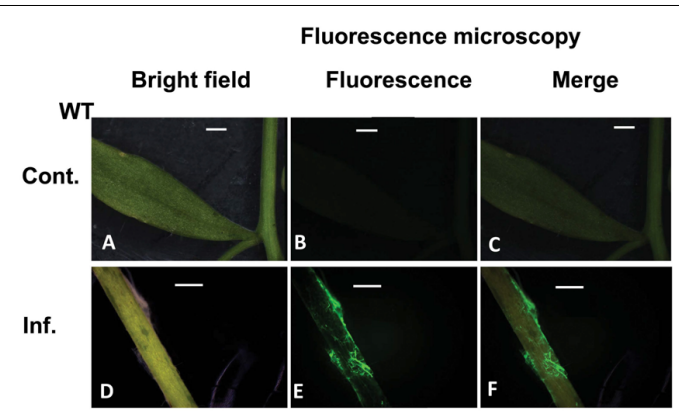

pdx1.3 mutant

Cont.
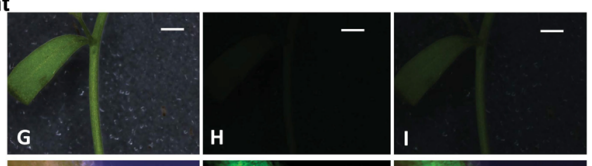

Inf.
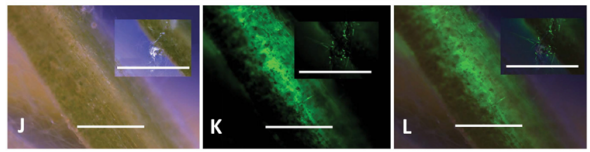

FIGURE 6 | Intracellular production of ROS during disease development in the Arabidopsis- $R$. solani AG4 interaction. Control not infected tissues under bright field (A) and under fluorescence $(\mathbf{B}, \mathbf{C})$ show no ROS production. Infected tissues (D) under bright field and under fluorescence (E,F) with ROS production as visualized using H2DCF-DA. Control mutant line (G) under bright field and under fluorescence $\mathbf{( H , I )}$ show no ROS. Infected mutant line under bright field $\mathbf{( J )}$ showing disease development (inset) and under fluorescence (K,L, insets) showing ROS production as visualized using H2DCF-DA. RB, Russet Burbank; Cont., control; Inf., infected; Col-o or WT, wild type. $\mathrm{Bar}=1 \mathrm{~mm}$.

in a manner consistent with increasing levels of VB6 mounting a pathogen response, but maintaining low expression levels in tissues bordering defense (zone 1). In sprouts of the tolerant potato cv. Chieftain infected with $R$. solani, an opposite transcript profile was established. A sharp increase in transcript abundance of these genes except for STPDX2 in the bordering tissue (zone1) was detected with increasing levels of VB6 content. This finetuning expression strategy of VB6 and GST genes, is most likely that the tolerant potato plants must sustain ROS levels at the site of infection to defend against the pathogen and to stimulate the defense response, yet keep ROS levels lower in regions (zone 1) not affected by the pathogen to maintain tissue integrity and viability. In potato, all STPDX genes are expressed with the highest expression of STPDX1.2 in sink areas such as tubers, roots, and stolons (Mooney et al., 2013). The role of the catalytic homolog STPDX1.1 in response to biotic and biotic stress and its involvement during disease development is established (Moccand et al., 2014; Samsatly et al., 2018). It is noteworthy that the non-catalytic STPDX1.2 is the most sensitive of STPDXs to biotic stress in this study.

We show that the expression of the STPDX1.2 is strongly downregulated in sprouts under biotic stress in both infected potato genotypes compared to the controls (this study; Samsatly et al., 2018), whereas its catalytic homologs are not. Our results do not support the decisive regulatory role of STPDX 1.2 with STPDX 2 (Dell'Aglio et al., 2017) as established in certain crops (Zhang et al., 2014), but likely supports the negative regulatory role of STPDX 1.2 with STPDX 2 in the tolerant potato genotype to $R$. solani. The differential regulation of VB6 could also involve cross-talk between de novo and the salvage gene pathway. This may imply that the salvage pathway may compensate for the absence of STPDX2 with corresponding high expression levels of the STPLR in the tolerant potato cv. Chieftain. Probably, the requirement of the salvage pathway for disease resistance in potato is essential. At this point, we cannot fully account for the observed downregulation of STPDX1.2 and STPDX2. An interesting finding that may be worth pursuing in the future is to understand how this diminution affects the regulation of VB6 biosynthesis.

In an attempt to understand how $R$. solani can regulate the levels of ROS for developmental and virulence purposes, we also compared the regulation of the fungal-derived VB6 genes of the biosynthetic pathways (de novo and salvage) and the antioxidant GST in cv. Russet Burbank and Chieftain
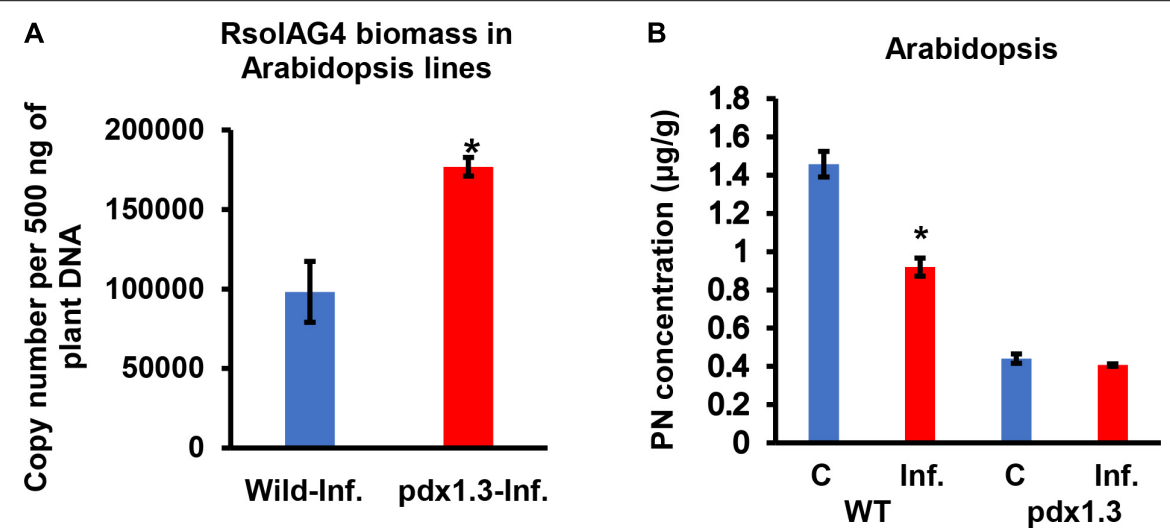

FIGURE 7 | Quantification of fungal gDNA (A) and concentration $(\mu \mathrm{g} / \mathrm{g})$ of Pyridoxine (PN) (B) in tissues of two Arabidopsis lines (WT, wild type, pdx1.3 mutant) during disease development of $R$. solani AG4 on Arabidopsis, 72 h post-infection (HPI). Fungal gDNA was measured using real-time quantitative PCR with 500 ng of plant samples. Asterisk indicates significant difference between control and infected tissues at $P<0.05$. WT, wild type; C, control; Inf., infected. 


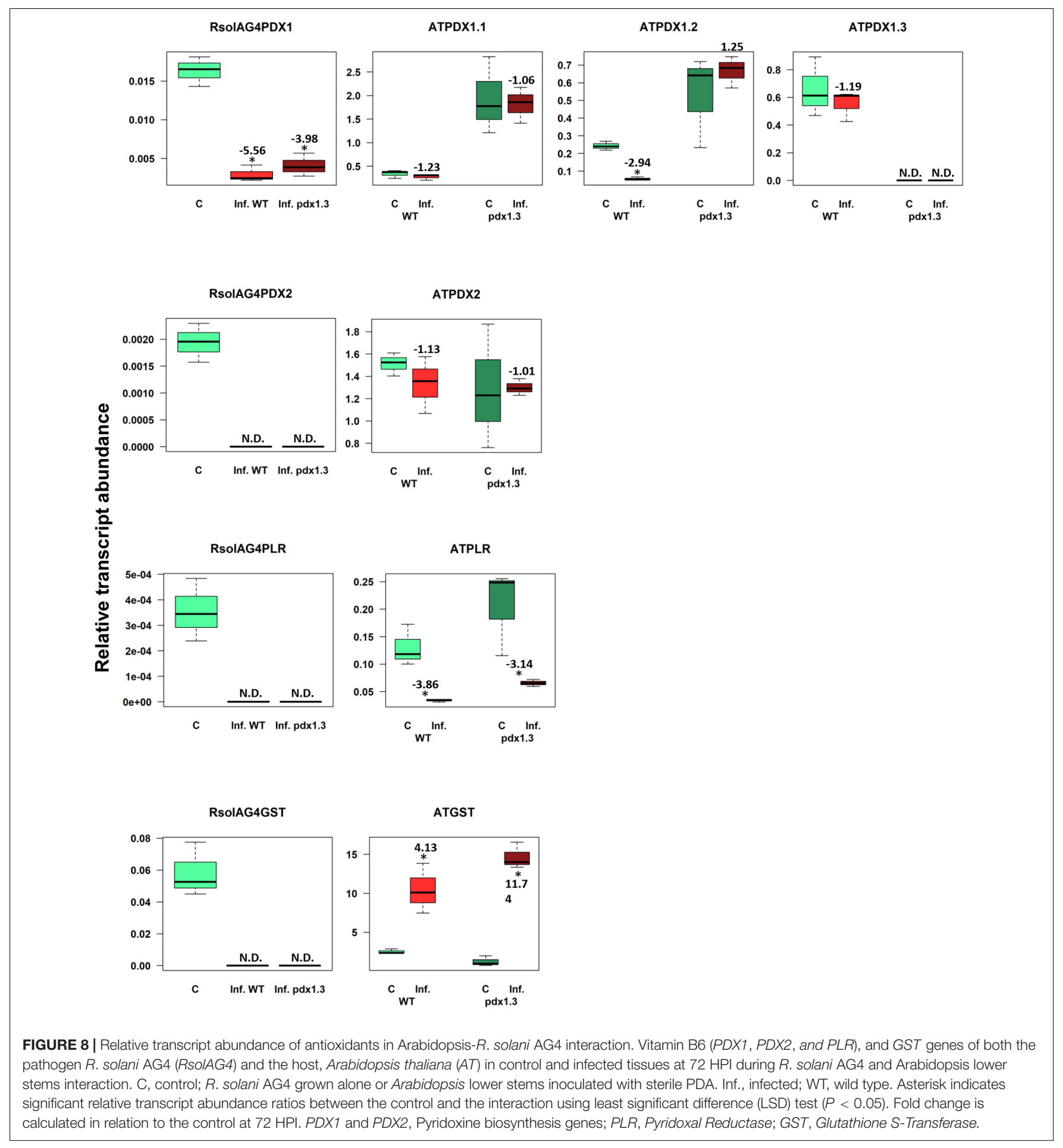

potato cultivars. Contrary to their counterpart in the plant, the activation of all VB6 encoding genes and GST was similar and comparable between both cultivars indicating they are essential for fungal pathogenicity. It is noteworthy that the escalated expression of all the genes were detected exclusively in areas surrounding the necrotic lesions (zone 1). This corroborates previous results of another study on gene regulation of $R$. solani antioxidants such as CAT, GST, and VB6 (Samsatly et al., 2018) indicating that transcript abundance of these genes are tissue-specific. The results of tissue specificity mesh well with the limited data published on the VB6 expression in different infected tobacco tissues (Denslow et al., 2005). Upon infection of tobacco leaves with $P$. syringae pv. Phaseolicola, levels of tobacco $P D X 1$ expression were higher in the area 
surrounding the infiltration area. This increase most likely indicates that pathogens invest more on turning their antioxidant arsenal outside the killing zone in the necrotic lesion in order to expand further.

To provide direct evidence supporting the role of potato PDX genes in plant biotic defense against $R$. solani, we examined the phenotypes of Arabidopsis mutants with defect in the de novo VB6 biosynthesis pathway against infections by $R$. solani AG4. We compared the changes of VB6 biosynthetic gene, ATPDX1.3 and VB6 (PN) contents in the wild type and $p d x 1.3$ plants before and after inoculation with $R$. solani AG4 strain A76. We selected Arabidopsis mutant defective in PDX1.3 instead of PDX1.2 because it is more requisite than PDX1.1 for VB6 synthesis (Titiz et al., 2006; Tambasco-Studart et al., 2007), and has a role in disease resistance against Pseudomonas syringae pv. tomato in Arabidopsis compared to ATPDX1.1 (Zhang et al., 2014, 2015). In this study, we examined the fungal load levels of $R$. solani and compared the in-planta fungal growth on the wild Col-0 and the mutant plants $p d x 1.3$. Analysis of R. solani AG4 PDX1 gene, indicative of $R$. solani fungal growth in planta, confirmed that $p d x 1.3$ mutant plants had consistently high levels of fungal load expressed as fungal biomass than the wild type plants. Coined with this significant increase of $R$. solani gDNA copies in the $p d x 1.3$ mutant, was the reduction of the VB6 vitamer PN compared to the infected wild-type. These results indicate that mutations in PDX1.3 gene resulted in increased susceptibility to $R$. solani. Similar trends were reported in studies dealing with interaction of the necrotrophic Botrytis with Arabidopsis $p d x 1.3$ mutant lines or tomato $s l p d x 1.3$ silenced lines that led to increased disease severity (Zhang et al., 2014, 2015). As expected, silencing of PDX1.3 but not PDX1.2 resulted in a decreased level of VB6 in the mutant plant. This is in agreement with what has been previously published (Wagner et al., 2006; Tambasco-Studart et al., 2007). Recent studies support the antioxidant role of VB6 and that it can modulate plant defense by regulation of the antioxidant status in plants that are under biotic stress. Such regulation is distinctively expressed and depends on the crop, tissue infected and the type of the pathogen such as in the case of tobacco-P. syringae pv. Phaseolicola, tomatoBotrytis cinerea, and tomato-Pseudomonas syringae pv (pst) or Arabidopsis-Pseudomonas syringae pv-Arabidopsis (Zhang et al., 2014, 2015). Taken together, molecular and biochemical data signify that VB6 and its de novo biosynthetic pathway are essential for the regulation of defense response through the modulation of cellular antioxidant capacity.

In this study, we also evaluated the expression of VB6 de novo (PDX2, PDX1.2, PDX 1.1) and the salvage pathway genes (ATPLR) and GST antioxidant gene in the $p d x 1.3$ mutant line, and in the wild type before and after infection. Expression analysis of the VB6 de novo biosynthetic pathway genes was similar in the control and infected wild and mutant lines. It has been reported that Arabidopsis (ATPDX1.2) is a pseudoenzyme that acts as a positive regulator of vitamin B6 abundance during abiotic stress (Moccand et al., 2014). The drop of VB6 vitamer PN content is most likely due to the drastic down-regulation of ATPDX1.2 in the infected wild type. On the other hand, the expression of ATPLR, a vital component in the VB6 salvage pathway, was downregulated in both infected lines which can also explain the drop in the VB6 content. This might also mean less ability of the Arabidopsis lines to resist the pathogen given the role of PLR in detoxification of ROS during biotic and abiotic stress (Morissette et al., 2008; Chamoun and Jabaji, 2011; Gkarmiri et al., 2015; Samsatly et al., 2015). It is noteworthy that ATGST gene was substantially overexpressed in the wild and mutant lines of Arabidopsis during disease development as compared to the mock-inoculated controls of both lines. The high induction of ATGST is likely required to scavenge excess ROS in response to $R$. solani infection and bring the generated toxic oxygen metabolites to balanced level between production and quenching (Torres, 2010; Sharma et al., 2012; Das and Roychoudhury, 2014).

We also evaluated the expression $R$. solani VB6 biosynthetic de novo genes (RsolPDX1, RsolPDX2), the salvage gene (RsolPLR) and RsolGST. Interestingly, most of the fungal VB6 and GST genes were not detected and RsolPDX1 was significantly suppressed. This pattern of down-regulation can result in an overflow of ROS in infected areas similar to what is found in other plant-necrotroph systems which appear to play an essential role during infection and initiation of the oxidative burst. For example, leaves of ivy pelargonium (Pelargonium peltatum) infected with Botrytis cinerea, exhibited a strong nitric oxide (NO) burst and hydrogen peroxide $\left(\mathrm{H}_{2} \mathrm{O}_{2}\right)$ accumulation to arrest disease progression through $\mathrm{NO}$-dependent reversible inhibition of catalase (Floryszak-Wieczorek et al., 2007).

PCA analysis identified vitamer $\mathrm{PN}$ as an important contributor during disease development in the potato$R$. solani and Arabidopsis- $R$. solani interactions. Analysis of $\mathrm{PN}$ in potato genotypes before and after inoculation with $R$. solani by LC-MS showed that in the absence of the pathogen, the VB6 contents in potato cv. Russet Burbank and $\mathrm{cv}$. Chieftain were approximately 21.6 and $13.7 \mu \mathrm{g} . \mathrm{g}^{-1}$, respectively, which are comparable to VB6 contents generally found in different potato genotypes (Mooney et al., 2013). On the other hand, the VB6 content in pdx1.3 mutant line of Arabidopsis was reduced by $70 \%$ lower as compared to that of the wild-type plants. This observation is in agreement that $p d x 1.3$ plants grown in sterile culture medium contain reduced VB6 content (Zhang et al., 2014). After infection of potato genotypes by $R$. solani AG3, the content of PN in the susceptible cv. Russet Burbank and in the moderately tolerant cv. Chieftain significantly increased by 1.4 and 1.7fold, respectively. The highest boost of PN in cv. Chieftain as compared to cv. Russet Burbank might be a factor leading to increased resistance to $R$. solani. This and the expression of VB6 PDX1.1, STPLR, and GST in tissues bordering the necrotic lesion is another factor that might determine the degree of susceptibility to $R$. solani. We put forward the assumption that the most important factor during disease development is not dependent on only how much PN is present prior to infection, but it is dependent on the ability of each plant to maintain or boost the production of PN at the right time and the right place. 
After infection by $R$. solani AG4, the VB6 content in Arabidopsis wild-type was significantly reduced by $37 \%$. However, the VB6 content in the infected $p d x 1.3$ mutant line was not affected and was similar to pdx1.3 mutant lines before infection. Our results indicate that reduced amounts of VB6 content lead to more Rhizoctonia infections in $p d x 1.3$ mutant lines. These results, along with the down-regulation of PDX1 in response to $R$. solani infections indicate that reduced biosynthesis and reduced VB6 content most likely represents a natural defense response in certain plants such as Arabidopsis, tomato, and tobacco against pathogenic infection (Denslow et al., 2005; Zhang et al., 2014, 2015). In contrast to what has been reported for Arabidopsis and other crops, it is not yet clear why the increased content of VB6 in potato genotypes led to more disease in the susceptible cultivar. Nevertheless, the data in this study provide direct evidence on the critical role of VB6 content in plant disease resistance.

It is common knowledge that ROS is generated at locations of attempted invasion through an oxidative burst during disease development (Alvarez et al., 1998; Lehtonen et al., 2008; Torres, 2010; Foley et al., 2016). ROS production was also reported in different anastomosis groups of $R$. solani that are pathogens of potato, soybean, sugar beet, and wheat. The induced ROS were also linked to the regulation of VB6 antioxidant genes and their collective possible role in oxidative stress alleviation (Taheri and Tarighi, 2011; Foley et al., 2016; Samsatly et al., 2018). Oxidative damage can be prevented in both the host and the pathogen when their antioxidant machinery is efficiently used (Apel and Hirt, 2004; Sharma et al., 2012). Microscopic analysis of Rhizoctonai solani AG3 and AG4 infections on stolons and stems confirmed that Rhizoctonia disease development in potato sprouts and Arabidopsis provokes an oxidative stress in fungal hyphae and plant tissues and could be related to the oxidative status of the fungus as well as the plant. Our data clearly showed that ROS formation was induced in the tissues of infected $\mathrm{cv}$. Russet Burbank and Chieftain sprouts, and Arabidopsis wild type and $p d x 1.3$ mutant lower stems. Tissues of infected potato cv. Russet Burbank sprouts displayed stronger brown precipitate pattern when compared to Chieftain specifically in zones 1 and 2 . This indicates that cv. Russet Burbank is experiencing a higher oxidative state and is less successful in quenching the $\mathrm{H}_{2} \mathrm{O}_{2}$ produced in the infected tissues.

\section{CONCLUSION}

This work portrays the importance of VB6 during disease development of $R$. solani over the different potato cultivars or different lines of Arabidopsis. Our study showed a distinct pattern of expression, PN concentration, and fungal load expressed as biomass between the cv. Russet Burbank and Chieftain. The characterization of Arabidopsis $p d x 1.3$ mutant line challenged with $R$. solani offers convincing evidence into the role of VB6 in maintenance and enhancement of plant tolerance against $R$. solani AG4. The results obtained suggests the VB6 role in resistance to oxidative stress resulting from biotic interaction of $R$. solani with its natural hosts. Last, the regulation and production of VB6 is under tight control and is an essential determinant of disease development of $R$. solani with potato or Arabidopsis.

\section{DATA AVAILABILITY STATEMENT}

All datasets generated for this study are included in the article/Supplementary Material.

\section{AUTHOR CONTRIBUTIONS}

JS and SJ: conception and design of the study and interpretation of data for the work. JS and SB: acquisition of data for the study and analysis of data for the work. JS, SB, and SJ: manuscript revision and approval. All authors contributed to the article and approved the submitted version.

\section{FUNDING}

Financial support, through a Discovery grant (RGPIN2016-04805) to SJ, was provided by the Natural Sciences and Engineering Research Council of Canada. The LC/MS infrastructure was funded by the Canada Foundation for Innovation/John R. Evans Leaders Fund Grant (Project \#35318) to SB.

\section{ACKNOWLEDGMENTS}

We thank D. Donnelly and K. Sabbally for providing certified seed potatoes of $\mathrm{cv}$. Russet Burbank. We greatly acknowledge J.-B. Charron for the use of the Zeiss SteREO Discovery.V20 microscope.

\section{SUPPLEMENTARY MATERIAL}

The Supplementary Material for this article can be found online at: https://www.frontiersin.org/articles/10.3389/fpls.2020.00875/ full\#supplementary-material

FIGURE S1 | Working conditions of Agilent 6540 Accurate-Mass QTOF.

FIGURE S2 | Genotyping for homozygous pdx1.3 mutants (SALK086418) and wild (Col-0) Arabidopsis plants using SALK gene-specific primer pairs and T-DNA primer LB1.3 along with SALK086418-RP.

FIGURE S3 | Principle component analysis score plots (PC1/PC2) for the effect of transcriptional abundance of antioxidant genes, PN concentrations, and fungal biomass on control, infected tissues in (A) pathosystem I (PC1/PC2), and (B-D) pathosystem II (PC1/PC2, PC1/PC3, and PC2/PC3) $(P<0.05)$. The ellipse represents the Hotelling T2 at a 95\% confidence interval. Three biological replications were performed per treatment. Q2 (cum); cumulative fraction of the total variation of the X's that can be predicted by the extracted components, R2X; the fraction of the sum of squares of the two principal components.

TABLE S1 | $p$-values of principal component analysis loading coefficient plots for potato- $R$. solani AG3 interaction.

TABLE S2 | $p$-values of principal component analysis loading coefficient plots for the Arabidopsis- $R$. solani AG4 interaction. 


\section{REFERENCES}

Abd-El-Haliem, A. (2012). "An unbiased method for the quantitation of disease phenotypes using a custom-built macro plugin for the program ImageJ," in Plant Fungal Pathogens. Methods in Molecular Biology (Methods and Protocols), Vol. 835, eds M. Bolton and B. Thomma (Totowa, NJ: Humana Press).

Aliferis, K. A., Faubert, D., and Jabaji, S. (2014). A metabolic profiling strategy for the dissection of plant defense against fungal pathogens. PLoS One 9:e111930. doi: 10.1371/journal.pone.0111930

Alonso, J. M., Stepanova, A. N., Leisse, T. J., Kim, C. J., Chen, H., Shinn, P., et al., (2003). Genome-wide insertional mutagenesis of Arabidopsis thaliana. Science 301, 653-657. doi: 10.1126/science.1086391

Alvarez, M. E., Pennell, R. I., Meijer, P. J., Ishikawa, A., Dixon, R. A., and Lamb, C. (1998). Reactive oxygen intermediates mediate a systemic signal network in the establishment of plant immunity. Cell 92, 773-784. doi: 10.1016/S00928674(00)81405-1

Apel, K., and Hirt, H. (2004). Reactive oxygen species: metabolism, oxidative stress, and signal transduction. Annu. Rev. Plant Biol. 55, 373-399. doi: 10.1146/ annurev.arplant.55.031903.141701

Bagri, D. S., Upadhyaya, D. C., Kumar, A., and Upadhyaya, C. P. (2018). Overexpression of PDX-II gene in potato (Solanum tuberosum L.) leads to the enhanced accumulation of vitamin B6 in tuber tissues and tolerance to abiotic stresses. Plant Sci. 272, 267-275. doi: 10.1016/j.plantsci.2018.04.024

Barna, B., Fodor, J., Harrach, B. D., Pogany, M., and Kiraly, Z. (2012). The Janus face of reactive oxygen species in resistance and susceptibility of plants to necrotrophic and biotrophic pathogens. Plant Physiol. Biochem. 59, 37-43. doi: 10.1016/j.plaphy.2012.01.014

Baumgartner, K., Bhat, R., and Fujiyoshi, P. (2010). A rapaid infection assay of Armillaria and real time PCR quantitiation of the fungl biomass in plant. Fungal Biol. 114, 107-119. doi: 10.1016/j.mycres.2009.11.003

Benabdellah, K., Azcon-Aguilar, C., Valderas, A., Speziga, D., Fitzpatrick, T. B., and Ferrol, N. (2009). GintPDX1 encodes a protein involved in vitamin B6 biosynthesis that is up-regulated by oxidative stress in the arbuscular mycorrhizal fungus Glomus intraradices. New Phytol. 184, 682-693. doi: 10. $1111 /$ j.1469-8137.2009.02978.x

Chamoun, R., and Jabaji, S. (2011). Expression of genes of Rhizoctonia solani and the biocontrol Stachybotrys elegans during mycoparasitism of hyphae and sclerotia. Mycologia 103, 483-493. doi: 10.3852/10-235

Chandrasekaran, M., and Chun, S. C. (2018). Vitamin B6 biosynthetic genes expression and antioxidant enzyme properties in tomato against, Erwinia carotovora subsp. carotovora. Int. J. Biol. Macromol. 116, 31-36. doi: 10.1016/j. ijbiomac.2018.05.024

Das, K., and Roychoudhury, A. (2014). Reactive oxygen species (ROS) and response of antioxidants as ROS-scavengers during environmental stress in plants. Front. Environ. Sci. 2:53. doi: 10.3389/fenvs.2014.00053

Daub, M. E., and Ehrenshaft, M. (2000). The photoactivated cercospora toxin cercosporin: contributions to plant disease and fundamental biology. Annu. Rev. Phytopathol. 38, 461-490. doi: 10.1146/annurev.phyto.38.1.461

Dell'Aglio, E., Boycheva, S., and Fitzpatrick, T. B. (2017). The pseudoenzyme PDX1. 2 sustains vitamin B6 biosynthesis as a function of heat stress. J. Plant Physiol. 174, 2098-2112. doi: 10.1104/pp.17.00531

Denslow, S. A., Walls, A. A., and Daub, M. E. (2005). Regulation of biosynthetic genes and antioxidant properties of vitamin B6 vitamers during plant defense responses. Physiol. Mol. Plant Pathol. 66, 244-255. doi: 10.1016/j.pmpp.2005. 09.004

Dowley, L. J. (1972). Varietal susceptibility of potato tubers to Rhizoctonia solani in Ireland. Irish J. Agr. Food Res. 11, 281-285.

Ehrenshaft, M., Bilski, P., Li, M. Y., Chignell, C. F., and Daub, M. E. (1999). A highly conserved sequence is a novel gene involved in de novo vitamin B6 biosynthesis. Proc. Natl. Acad. Sci. U.S.A. 96, 9374-9378. doi: 10.1073/pnas.96.16.9374

Fitzpatrick, T. B., Amrhein, N., Kappes, B., Macheroux, P., Tews, I., and Raschle, T. (2007). Two independent routes of de novo vitamin B6 biosynthesis: not that different after all. Biochem. J. 407, 1-13. doi: 10.1042/BJ20070765

Fitzpatrick, T. B., Basset, G. J. C., Borel, P., Carrari, F., DellaPenna, D., Fraser, P. D., et al., (2012). Vitamin deficiencies in humans: can plant science help? Plant Cell 24, 395-414. doi: 10.1105/tpc.111.093120

Floryszak-Wieczorek, J., Arasimowicz, M., Milczarek, G., Jelen, H., and Jackowiak, H. (2007). Only an early nitric oxide burst and the following wave of secondary nitric oxide generation enhanced effective defence responses of pelargonium to a necrotrophic pathogen. New Phytol. 175, 718-730. doi: 10.1111/j.1469-8137. 2007.02142.x

Foley, R. C., Kidd, B. N., Hane, J. K., Anderson, J. P., and Singh, K. B. (2016). Reactive oxygen species play a role in the infection of the necrotrophic fungi, Rhizoctonia solani in wheat. PLoS One 11:e0152548. doi: 10.1371/journal.pone. 0152548

Gachon, C., and Saindrenan, P. (2004). Real-time PCR monitoring of fungal development in Arabidopsis thaliana infected by Alternaria brassicicola and Botrytis cinerea. Plant Physiol. Biochem. 42, 367-371. doi: 10.1016/j.plaphy. 2004.04.001

Girard, I. J., Tong, C., Becker, M. G., Mao, X., Huang, J., de Kievit, T., et al., (2017). RNA sequencing of Brassica napus reveals cellular redox control of Sclerotinia infection. J. Exp. Bot. 68, 5079-5091. doi: 10.1093/jxb/erx338

Gkarmiri, K., Finlay, R. D., Alstrom, S., Thomas, E., Cubeta, M. A., and Hogberg, N. (2015). Transcriptomic changes in the plant pathogenic fungus Rhizoctonia solani AG-3 in response to the antagonistic bacteria Serratia proteamaculans and Serratia plymuthica. BMC Genomics 16:630. doi: 10.1186/s12864-0151758-z

González-Guerrero, M., Cano, C., Azcón-Aguilar, C., and Ferrol, N. (2007). GintMT1 encodes a functional metallothionein in Glomus intraradices that responds to oxidative stress. Mycorrhiza 17, 327-335. doi: 10.1104/pp.107. 105189

Gutierrez, W. A., Shew, H. D., and Melton, T. A. (1997). Sources of inoculum and management for Rhizoctonia solani Damping-off on tobacco transplants under greenhouse conditions. Plant Dis. 81, 604-606. doi: 10.1094/PDIS.1997. 81.6.604

Heller, J., and Tudzynski, P. (2011). Reactive oxygen species in phytopathogenic fungi: signaling, development, and disease. Annu. Rev. Phytopathol. 49, 369390. doi: 10.1146/annurev-phyto-072910-095355

Hellmann, H., and Mooney, S. (2010). Vitamin B6: a molecule for human health? Molecules 15, 442-459. doi: 10.3390/molecules 15010442

Herrero, S., Gonzailez, E., Gillikin, J. W., Veile??z, H., and Daub, M. E. (2011). Identification and characterization of a pyridoxal reductase involved in the vitamin B6 salvage pathway in Arabidopsis. Plant Mol. Biol. 76, 157-169. doi: 10.1007/s11103-011-9777-x

Hide, G., Welham, S., Read, P., and Ainsley, A. (1996). The yield of potato plants as affected by stem canker (Rhizoctonia solani), blackleg (Erwinia carotovora subsp. atroseptica) and by neighbouring plants. J. Agric. Sci. 126, 429-440. doi: 10.1017/S0021859600075511

Hide, G. A., and Horrocks, J. K. (1994). Influence of stem canker (Rhizoctonia solani Kühn) on tuber yield, tuber size, reducing sugars and crisp colour in $\mathrm{cv}$. Record. Potato Res. 37, 43-49. doi: 10.1007/BF02360431

Johanson, A., Turner, H. C., McKay, G. J., and Brown, A. E. (1998). A PCR-based method to distinguish fungi of the rice sheath-blight complex, Rhizoctonia solani, R. oryzae and R. oryzae-sativae. FEMS Microbiol. Lett. 162, 289-294. doi: 10.1111/j.1574-6968.1998.tb13011.x

Kadota, Y., Shirasu, K., and Zipfel, C. (2015). Regulation of the NADPH oxidase RBOHD during plant immunity. Plant Cell Physiol. 56, 1472-1480. doi: 10. 1093/pcp/pcv063

Keijer, J. (1996). “The initial steps of the infection process in Rhizoctonia solani," in Rhizoctonia Species: Taxonomy, Molecular Biology, Ecology, Pathology and Disease Control, eds B. Sneh, S. Jabaji-Hare, S. Neate, and G. Dijst (Dordrecht: Springer), 149-162. doi: 10.1007/978-94-017-2901-7_13

King, R., Urban, M., Hammond-Kosack, M. C., Hassani-Pak, K., and HammondKosack, K. E. (2015). The completed genome sequence of the pathogenic ascomycete fungus Fusarium graminearum. BMC Genomics 16:544. doi: 10. 1186/s12864-015-1756-1

Laluk, K., and Mengiste, T. (2010). Necrotroph attacks on plants: wanton destruction or covert extortion? Arabidopsis Book 8:e0136. doi: 10.1199/tab. 0136

Lehtonen, M., Somervuo, P., and Valkonen, J. (2008). Infection with Rhizoctonia solani induces defense genes and systemic resistance in potato sprouts grown without light. Phytopathology 98, 1190-1198. doi: 10.1094/PHYTO-98-111190

Libault, M., Thibivilliers, S., Bilgin, D. D., Radwan, O., Benitez, M., Clough, S. J., et al., (2008). Identification of four soybean reference genes for gene expression normalization. Plant Genome 1, 44-54. doi: 10.3835/plantgenome2008.02.0091 
Moccand, C., Boycheva, S., Surriabre, P., Tambasco-Studart, M., Raschke, M., Kaufmann, M., et al., (2014). The pseudoenzyme PDX1.2 boosts vitamin B6 biosynthesis under heat and oxidative stress in Arabidopsis. J. Biol. Chem. 289, 8203-8216. doi: 10.1074/jbc.M113.540526

Mooney, S., Chen, L., Kuhn, C., Navarre, R., Knowles, N. R., and Hellmann, H. (2013). Genotype-specific changes in vitamin B6 content and the PDX family in potato. Biomed. Res. Int. 2013:389723. doi: 10.1155/2013/389723

Mooney, S., Leuendorf, J. E., Hendrickson, C., and Hellmann, H. (2009). Vitamin B6: a long known compound of surprising complexity. Molecules 14, 329-351. doi: 10.3390/molecules14010329

Morissette, D. C., Dauch, A., Beech, R., Masson, L., Brousseau, R., and JabajiHare, S. (2008). Isolation of mycoparasitic-related transcripts by SSH during interaction of the mycoparasite Stachybotrys elegans with its host Rhizoctonia solani. Curr. Genet. 53, 67-80. doi: 10.1007/s00294-007-0166-6

Morita, T., Takegawa, K., and Yagi, T. (2004). Disruption of the plr1+ gene encoding pyridoxal reductase of Schizosaccharomyces pombe. J. Biochem. 135, 225-230. doi: 10.1093/jb/mvh026

Nardeli, S. M., Matta, B. P., Saad, C. F., Reinert, F., Peixoto, R. S., and AlvesFerreira, M. (2017). Early heat shock protein response and selection of reference genes in Arabidopsis thaliana seedlings subjected to marine fuel contamination. Water Air Soil Pollut. 228:101. doi: 10.1007/s11270-017-3251-6

Nikraftar, F., Taheri, P., Falahati Rastegar, M., and Tarighi, S. (2013). Tomato partial resistance to Rhizoctonia solani involves antioxidative defense mechanisms. Physiol. Mol. Plant Path 81, 74-83. doi: 10.1016/j.pmpp.2012.11.004

Raschle, T., Amrhein, N., and Fitzpatrick, T. B. (2005). On the two components of pyridoxal 5'-phosphate synthase from Bacillus subtilis. J. Biol. Chem. 280, 32291-32300. doi: 10.1074/jbc.M501356200

Rueschhoff, E. E., Gillikin, J. W., Sederoff, H. W., and Daub, M. E. (2012). The SOS4 pyridoxal kinase is required for maintenance of vitamin B6 mediated processes in chloroplasts. Plant Physiol. Biochem. 63, 281-291. doi: 10.1016/j.plaphy.2012. 12.003

Samsatly, J., Chamoun, R., Gluck-Thaler, E., and Jabaji, S. (2015). Genes of the de novo and salvage biosynthesis pathways of vitamin B6 are regulated under oxidative stress in the plant pathogen Rhizoctonia solani. Front. Microbiol. 6:1429. doi: 10.3389/fmicb.2015.01429

Samsatly, J., Copley, T. R., and Jabaji, S. H. (2018). Antioxidant genes of plants and fungal pathogens are distinctly regulated during disease development in different Rhizoctonia solani pathosystems. PLoS One 13:e0192682. doi: 10.1371/ journal.pone.0192682

Sharma, P., Jha, A. B., Dubey, R. S., and Pessarakli, M. (2012). Reactive oxygen species, oxidative damage, and antioxidative defense mechanism in plants under stressful conditions. J. Bot. 2012, 1-26. doi: 10.1155/2012/217037

Sneh, B., Jabaji-Hare, S., Neate, S., and Dijst, G. (2013). Rhizoctonia Species: Taxonomy, Molecular Biology, Ecology, Pathology and Disease Control. Berlin: Springer Science \& Business Media.

Stewart, E. L., Hagerty, C. H., Mikaberidze, A., Mundt, C. C., Zhong, Z., and McDonald, B. A. (2016). An improved method for measuring quantitative resistance to the wheat pathogen Zymospetoria tritici using highthroughput automoated image anaysis. Phytopathology 106, 782-788. doi: 10.1094/phyto01-16-0018-r
Taheri, P., and Tarighi, S. (2011). A survey on basal resistance and riboflavininduced defense responses of sugar beet against Rhizoctonia solani. J. Plant Physiol. 168, 1114-1122. doi: 10.1016/j.jplph.2011.01.001

Tambasco-Studart, M., Tews, I., Amrhein, N., and Fitzpatrick, T. B. (2007). Functional analysis of PDX2 from Arabidopsis, a glutaminase involved in vitamin B6 biosynthesis. Plant Physiol. 144, 915-925. doi: 10.1104/pp.107. 096784

Thangavel, T., Tegg, R. S., and Wilson, C. R. (2014). Resistance to multiple tuber diseases expressed in somaclonal variants of the potato cultivar Russet Burbank. Sci. World J. 2014:417697. doi: 10.1155/2014/417697

Titiz, O., Tambasco-Studart, M., Warzych, E., Apel, K., Amrhein, N., Laloi, C., et al., (2006). PDX1 is essential for vitamin B6 biosynthesis, development and stress tolerance in Arabidopsis. Plant J. 48, 933-946. doi: 10.1111/j.1365-313X.2006. 02928.x

Torres, M. A. (2010). ROS in biotic interactions. Physiol. Plant. 138, 414-429. doi: 10.1111/j.1399-3054.2009.01326.x

Torres, M. A., Jones, J. D., and Dangl, J. L. (2005). Pathogen-induced, NADPH oxidase-derived reactive oxygen intermediates suppress spread of cell death in Arabidopsis thaliana. Nature Genet. 37:1130.

Vanderschuren, H., Boycheva, S., Li, K.-T., Szydlowski, N., Gruissem, W., and Fitzpatrick, T. B. (2013). Strategies for vitamin B6 biofortification of plants: a dual role as a micronutrient and a stress protectant. Front. Plant Sci. 4:143. doi: $10.3389 /$ fpls. 2013.00143

Wagner, S., Bernhardt, A., Leuendorf, J. E., Drewke, C., Lytovchenko, A., Mujahed, N., et al., (2006). Analysis of the Arabidopsis rsr4-1/pdx1-3 mutant reveals the critical function of the PDX1 protein family in metabolism, development, and vitamin B6 biosynthesis. Plant Cell 18, 1722-1735. doi: 10.1105/tpc.105.03 6269

Zhang, Y., Jin, X., Ouyang, Z., Li, X., Liu, B., Huang, L., et al., (2015). Vitamin B6 contributes to disease resistance against Pseudomonas syringae pv. tomato DC3000 and Botrytis cinerea in Arabidopsis thaliana. J. Plant Physiol. 175, 21-25. doi: 10.1016/j.jplph.2014.06.023

Zhang, Y., Liu, B., Li, X., Ouyang, Z., Huang, L., Hong, Y., et al., (2014). The de novo biosynthesis of vitamin B6 is required for disease resistance against Botrytis cinerea in tomato. Mol. Plant Microbe Interact. 27, 688-699. doi: 10. 1094/MPMI-01-14-0020-R

Zhoa, S., and Fernald, R. D. (2005). Comprehensive algorithm for quantitative realtime polymerase chain reaction. J. Comput. Biol. 12, 1047-1064. doi: 10.1089/ cmb.2005.12.1047

Conflict of Interest: The authors declare that the research was conducted in the absence of any commercial or financial relationships that could be construed as a potential conflict of interest.

Copyright (c) 2020 Samsatly, Bayen and Jabaji. This is an open-access article distributed under the terms of the Creative Commons Attribution License (CC BY). The use, distribution or reproduction in other forums is permitted, provided the original author(s) and the copyright owner(s) are credited and that the original publication in this journal is cited, in accordance with accepted academic practice. No use, distribution or reproduction is permitted which does not comply with these terms. 